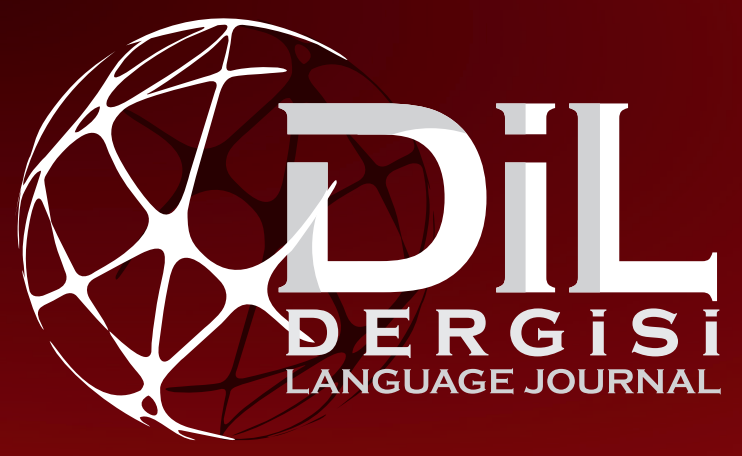

Dil Dergisi

Sayı/Number: 171/2

Haziran/June 2020

Gönderildiği tarih: 18.03.2020

Kabul edildiği tarih: 12.05.2020

DOI: $10.33690 /$ dilder.703005

Anahtar Sözcükler

Biçimbilim; Bileşik sözcük; Bileşik eki; Türetimsel dizil;

İlgi işlevi; Ad tamlaması
Keywords

Morphology; Compound; Compound marker;

Derivational paradigm; Association; Noun phrase

\title{
TÜRKÇEDE BİLEŞiK EKI VE TÜRETIMSEL DiZIL
}

\section{TURKISH COMPOUND MARKER AND THE DERIVATIONAL PARADIGM}

\section{- Aysun Kunduracı}

Dr. Öğr. Üyesi, Yeditepe Üniversitesi, Eğitim Fakültesi, Yabancı Diller Eğitimi Bölümü, kunduraca@gmail.com, ORCID NO: 0000-0001-5250-7899

$\ddot{O z}$

Bu çalışma, Türkçede geleneksel yaklaşımlarda belirtisiz ad tamlaması olarak bilinen, üretken $a d+a d+(s) l(n)$ biçimindeki bileşikleri Süreçsel Biçimbilim (bkz. Zwicky, 1986; Aronoff, 1994; Pounder, 2000) çerçevesinde ele almakta, bileşikler için yapısal ve anlamsal bir çözümleme sunmakta ve bileşiklerde eklenen -(s)I(n) eki için yeni bir işlev önermektedir. Bileşiklerdeki -(s)I(n) ekine türetimsel ve saf biçim(bilgi)sel bir görev (bileşik tabanları biçimleme) yükleyen çalışma, bu ekin eklenme sürecini de içeren belli bir grup türetim işleminden sorumlu bir dizil (ing. paradigm) yapısı önermekte, -(s) I(n)’ın bir grup türetim ekiyle dizilsel bir ilişki içinde olduğunu göstermektedir. Dizil yapısı, yalnızca $-(s) I(n)$ eklenmesini değil, daha önce değinilmeyen, anlamsal olarak beklendiği halde bu ekin eklenmediği durumları da açıklamaktadır, örn. badem şeker-ci(-si). Çalışma, kuramsal açıdan da biçimbilimi (ve biçimbilgisel işlemleri) sözdizim ve sözlükçeye bağımlı olmayan ayrı bir dizge olarak kabul etmekte; anlam ve biçimin ayrı düzlemler olduğunu çeşitli dillerden veriyle vurgulayan süreçsel yaklaşımlara Türkçeden destekler sunmakta ve böylelikle biçimbilimdeki Ayrıklık Varsayımı'na (Beard, 1995) doğrudan gönderim yapmaktadır. Çalışma, ayrıca, biçimbilimde özerk biçimsel işlemlerin uygulandığı girdilere, yani tabanlara, ışık tutmakta ve hem türetimsel hem de çekimsel biçimbilgisi açısından tabanların önemini ortaya çıkarmaktadır.

\section{Abstract}

This study deals with the productive $N-N-(s) I(n)$ compounds in Turkish (so-called indefinite noun phrases, traditionally) within a Process-Morphology approach (cf. Zwicky, 1986; Aronoff, 1994; Pounder, 2000), and presents a structural and a semantic analysis, which includes a new function for the $-(s) I(n)$ suffixation in the compounds. Assigning a derivational and barely morphological function to the - $(s) l(n)$ in compounds, which is stem formation, the study proposes a derivational paradigm where $-(s) I(n)$ is involved in a paradigmatic relation with a group of derivational suffixes. Importantly, the paradigm structure explains not only the existence but also the absence of the compound marker in contexts where it would be expected to occur semantically. Theoretically, the study (i) assumes that the morphology (and morphological operations) is not manipulated by either the syntax or the lexicon, but an autonomous subsystem of the grammar, (ii) supports the Separationism Hypothesis (Beard, 1995) with Turkish data showing that form and meaning are separate levels, as is highlighted in other process approaches exploring other languages. The study also offers an insight into the descriptive and theoretical status of the inputs of morphological operations, i.e. stems, which gain prominence both in derivational and inflectional morphology. 


\section{Konu ve Amaç}

Bu çalışma Türkçede badem şeker- $\underline{i}$ türünden ad-ad tabanlı bileşiklerin ${ }^{1}$ üretimi, bu yapıdaki $-(s) !(n)^{2}$ ekinin işlevi, eklenme süreci ve bu yapının badem şeker-li, badem şeker-siz, badem şeker-ci, badem şeker-ci-si ve badem şeker-ciğ-i gibi türetimlerle olan ilişkisi üzerinedir. Çalışma, bu türetimler arasındaki ilişkiden sorumlu bir sözcük oluşturma dizili (ìng. paradigm) önermektedir. Bilindiği gibi dizillerin önemi alanyazınında genellikle çekimsel ilişkileri açıklarken ortaya çıkmaktadır, bkz. örn. Wurzel (1989), Plank (1991), Anderson (1982), Stump (1991), Carstairs-McCarthy (1998), Spencer (2001). Bunun yanında, kısıtlı sayıda da olsa, çekim yerine türetim alanında diziller öneren çalışmalar da vardır: Guilbert (1975), Pounder (2000), Blevins (2001) gibi. Bu çalışma da bu ikinci grup çalışmalarda olduğu gibi dizillerin (ya da dizil yapılarının) türetimsel biçimbilimdeki önemini göstermekte ve Türkçede, yukarıdaki badem şeker- tabanlı biçimlerle örneklendiği gibi, hem biçimsel hem de anlamsal ortaklıkları olan ad-ad tabanlı sözcük türetimlerine bir dizil yapısıyla ışık tutmaktadır.

Çalışma (i) Türkçede badem şeker-ị türünden bileşiklerde neden -(s)I(n)'ın gerekli olduğunu ve bunun aksine kimi zaman eklenememesini, örneğin *badem-şeker-i-ili, (ii) bileşik oluşumu ve türetim arasındaki ilişkiyi (iii) dizillerin durağan değil devinik yapılar olduğunu göstermeyi ve (iv) Türkçe için sunulan çözümlemelerle biçimyapısal ${ }^{3}$ dizgenin genel işleyişiyle ilgili alana katkıda bulunmayı hedeflemektedir. Yukarıda örneklendiği gibi -(s)ı(n) ekinin kimi zaman belirip kimi zaman belirmemesi ve kimi eklerle yan yana gelip kimileriyle gelmemesinin dışında, kim-in şeker-i gibi iyelik öbeklerinde de karşımıza çıkması bu eki daha da ilginç kılsa da bu çalışmada yalnızca ad-ad bileşikleri ve -(s)I(n)'ın bu ortamdaki işlevi incelenmektedir. ${ }^{4}$

-(s)I(n) eki, yukarıda bahsedildiği gibi hem ad-ad bileşiklerinde hem de iyelik öbeklerinde kullanılması sebebiyle önceki kimi çalışmalara da konu olmuştur. Bu ekle ilgili iki temel yaklaşımdan ilkine göre ad-ad bileşiklerindeki $-(s) I(n)$ iyelik öbeklerindekiyle aynıdır: 3.kişi iyelik eki, örn. bkz. Underhill (1976), Yükseker (1987), Lewis (2000), Uygun (2009). Bunun aksine Swift (1963), Hayasi (1996), Schaaik (1996), Schroeder (1999), Bozşahin (2002), Göksel ve Kerslake (2005), Göksel (2009), Aslan ve Altan (2006), Kharytonava (2011)'de -(s)I(n) ad-ad bileşiklerinde bir bileşik göstericisi iken iyelik öbeklerinde 3. tekil kişi ekidir, yani iki ayrı ortamda iki ayrı -(s) I(n) vardır. Bu çalışma da bu ikinci çok işlevli görüşü izlemekle beraber, $-(s) I(n)$ ekinin ad-ad

1 Bu çalışmada taban ingilizcede base/stem için ve bileşik terimi de alanyazınındaki bileşik sözcük ve birleşik (Ing."compound") terimleri için kullanılmaktadır.

2 Bu ek -I, -i, -u, - ̈̈, -sı, -si, -su, -sü ve durum çekiminden önce -sln olarak kullanılmaktadır.

3 Bu çalışma, biçimbilgisine ait yapıya odaklanırken biçimyapısı terimini kullanmaktadır.

4 -(s)I(n)'nın oluştuğu bu iki ortamın karşılaştıııldığı çalışmalar için örneğin bkz. Kornfilt, 1984; Yükseker, 1994, 1998; Hayasi; 1996, Bozşahin, 2002; Göksel, 2009; Kharytonava, 2011; Kunduracı, 2013, 2017. 
bileşiklerindeki görevinin bileşik gösterme eki olmaktan öte, türetimsel olarak biçimsel taban oluşturma olduğunu göstermektedir (bkz. Kunduracı, 2017, 2019a).

Çalışmanın değindiği diğer bir nokta da bileşiklerin ve bileşik oluşumunun, yani bileşim/ bileştirme işleminin, genel dilbilgisi dizgesindeki yeridir, ki bu da tartş̧malı bir konudur. Bu konuyla ilgili olarak yine iki temel yaklaşımdan bahsedebiliriz: bileşikleri sözlüksel oluşumlar olarak gören yaklaşım, örneğin Jackendoff (1975), Lieber (2004) ve bileşikleri sözdizimsel oluşumlar olarak gören karşıt yaklaşım, örneğin Borer (2009) ve Harley (2009) gibi. Sözlüksel yaklaşımı benimseyenler aynı zamanda Sözlüksel Bütünlük İlkesi'ni (The Lexical Integrity Principle, Lapointe, 1980) benimsediğinden, bu yaklaşıma göre sözdizimsel işlemlerin sözlüksel biçimlerin iç yapısını etkilemesi ve oluşturması söz konusu değildir. Bu sebeple bu yaklaşımda bileşikler ve öbeksi yapılar arasındaki belirgin farklılıklar rahatılıkla açıklanabilir. Örneğin ad-ad bileşiklerindeki ögelerin yapısal ayrılmazlığı (bkz. elma (*her) ağac-ı), ilk ögenin genel gönderimli olması, bu yapıların kimi dillerdeki kendilerine özgü bürünsel özellikleri, bileşiklerin, öbeksi yapıların aksine, sözlükçede oluştuğu varsayılarak açıklanmaktadır. Ancak sözlüksel yaklaşımın açıklayamadığı önemli bir durum vardır: öbeksi bileşikler. Öbekli bileşikler derken içinde yerleşik sözdizimsel yapılar barındıran bileşiklerden bahsedilmektedir, örneğin [yeşil elma] ağac-ı. Bu gibi üretken yapılar yukarıda bahsedilen Sözlüksel Bütünlük İlkesi'ni açıkça yıkmaktadır çünkü sözlüksel olduğu düşünülen birimlerin içinde öbeksi yapılanma söz konusudur. Diğer, sözdizimsel görüşe baktığımızda da bu tip öbekli bileşiklerin kolayca açıklanabildiğini görürüz: Bileşiklerin öbek barındırması sorun değildir çünkü her iki yapı da, hem bileşik hem öbek, sözdizimsel işlemlerle üretilmektedir. Ancak, sözdizimsel yaklaşımın da açıklayamadığı bir durum vardır: bileşikleri öbeklerden ayıran özellikler (yukarıda bahsedilen). Örneğin Türkçede, yukarıda örneklendiği ve alanyazınında da daha önce değinildiği gibi, ad-ad bileşiklerinde görülen yapısal ayrılmazlık, benzeri öbeklerde (iyelik öbeklerinde) görülmemektedir; ad-ad bileşiklerinde baş öge bağımlı ögeye durum yükleyemezken iyelik öbeklerinde ilgi/tamlayan durumunu yüklemektedir. Yine ad-ad bileşiklerinde ilk birim tek başına, bileşik dışından bir birime gönderim yapamamakta (1a) ancak iyelik öbeklerindeki (ilgi ekli) öge, öbek dışı birimlerle eşgönderimsel bir ilişki kurabilmektedir (1b), bkz. (1):
a. $\left\{\right.$ çocuk $_{i}$
(*yeni)

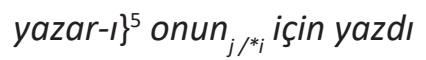
b. [çocuğ-un

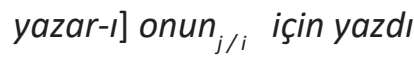

5 Bu çalışmada süslü ayraçlar biçimbilimsel, köşeli ayraçlar da sözdizimsel birimler için kullanılmaktadır. 
Ad-ad bileşiklerine getirilecek çözümleme (i) bu yapıları öbeklerden ayıran yukarıdaki belirgin özellikleri, (ii) bu özgün yapının nasıl olup da öbek içerebildiğini ([yeşil elma] ağacı gibi öbekli bileşikleri), (iii) -(s)I(n) ekinin bileşiklerdeki işlevini ve de yukarıda gösterildiği gibi (iv) bu ekin belirli türetim ekleriyle birlikte eklenememesini açıklamalıdır. ${ }^{6}$ Bileşik oluşumunu sözlükçeye ya da sözdizime yüklemek de kimi sorunları çözerken diğerlerini çözümsüz bırakmaktadır, yukarıda bahsedildiği gibi. Bu çalışma bu sorunlar için çözümler sunmakta ve aynı zamanda Türkçeye özgü işlemler aracılığıyla biçimyapısının dil dizgesindeki genel işleyişiyle ilgili alanlara katkıda bulunmayı amaçlamaktadır.

Çalışma betimleyici ve durum belirleyici bir yöntem izlemekte ve şu şekilde ilerlemektedir: Ad-ad bileşikleri ve $-(s) l(n)$ ekiyle ilgili temel araştrrma soru(n)larını sunan bu giriş bölümü -(s) I(n)'ı ad-ad bileşiklerindeki anlam çözümlemesinin sunulduğu ikinci bölüm izlemektedir (§2). Bu bölümün ardından, üçüncü bölümde (§3), bileşiklerin yapısal çözümlemesi -(s)l(n) ekinin eklenme süreciyle birlikte) ve bileşiklerin belli türetim süreçleriyle olan yapısal ilişkisi sunulmaktadır. Çalışma bu ilişkinin türetimsel bir dizil yapısına dayandığını öne sürmekte ve bu savı hem yapısal hem de anlamsal olarak desteklemektedir. Bu bölümü izleyen bölümde (§4), bileşiklerin çoğul ve çekimli biçimlerinin çalışmaya katkısı tartsşılmakta; $-(s)$ I(n) ekinin bileşik içeren iyelik öbeklerinde aitlik ekleriyle birlikte oluşamamasına değinilmekte ve ilgili dilbilgisidışı ek dizilimlerine süreçsel biçimbilimsel bir çözümleme getirilmektedir. Son bölüm olan §5’te de Türkçeye özel ve dilbilgisi sistemiyle ilgili genel sonuçlar sunulmaktadır. ${ }^{7}$

\section{Anlamsal Çözümleme}

Bu bölüm bileşiklerin içerdiği ancak sıradan ad öbeklerinin içermediği özel anlamı irdelemekte ve bileşiklerdeki bu anlamın asında baş ve bağımlı öge arasında kurulan bir grup anlambilimsel ilişkiye (işleve) dayandığını öne sürmektedir. Çalışmada, iki öge arasında bir tür ilgi ilişkisi kuran bu anlamsal ilişkiler kısaca "ilgi işlevleri" olarak tanımlanmakta ve bileşiklerde istenilen anlamın oluşmasında bu işlevlerin temel etmen olduğu varsayılmaktadır. ${ }^{8}$ Böyle bir yaklaşım, aynı zamanda pek çok türe-dayalı anlambilim (İng. type-driven semantics) modelinde olduğu gibi ve Jackendoff'un (2009) önerdiği gibi üretici bir anlambilimsel bileşen olduğunu varsaymaktadır.

$6-(s) l(n)$ eki için sunulan çözümleme, bu noktaları göz ardı ederse eksik bir çözüm olarak kalacaktır.

7 Çalışmada kullanılan kısaltmalar şu şekildedir: Aiт: aitlik, AK: anlamsal kural, AÖ: ad öbeği, BK: biçimsel kural, çOK: çoğul/çokluk, KK: kural koşulu, í: İ̧̧lem (operasyon) koşulu, TEK: tekil/teklik, TK: taban koşulu.

8 Bu çalışmada olduğu gibi, Levi (1978) İngilizce ve Pounder (2000) Almanca ad-ad bileşiklerinde belirli bir grup anlambilimsel işlevin etkili olduğunu savunmaktadır. Bu görüşün aksine Kay ve Zimmer (1976) ve Spencer (2011) bileşiklerdeki anlamı yalnızca edimbilimsel bağlama yüklemektedir. 
Örneğin, bahar badem-i bileşiğindeki anlamsal ilişki çiğ badem öbeğindeki anlamsal ilişkiden farklıdır. çiğ badem öbeğindeki ilişkinin aksine, bahar badem-i bileşiğinde iki ögenin anlamının yanında bir de 'ilgi' işlevi vardır: 'bahar'a ait olan/baharda üretilen bir tür badem'dir bahar badem-i. Burada bileşen iki öge arasında biçimsel olarak görünmeyen ve yalnızca anlamsal olarak var olan bir işlev vardır: iLGi. Bu açıdan Türkçede ad-ad bileşikleri ad öbeklerinden ayrılır. Bileşiklerdeki bu özel anlamsal durum bileşikteki bağımlı ögenin (ilk ögenin) ulamından, yani yapıda örneğin bir sıfat ve bir ad yerine iki ad bulunmasından kaynaklanıyor da olamaz. Çünkü iki ad içeren her yapı ilgi işlevi içermemektedir. Örneğin çocuk şair yapısı da bahar bademi gibi iki ad içermekte ancak herhangi bir ilgi ilişkisi içermemektedir. çocuk şair gibi bir yapı aynı zamanda ayrılabilir olduğundan, örneğin çocuk bir şair ifadesinde olduğu gibi, bu çalışmaya göre bileşik değil, yetenekli şair gibi bir ad öbeğidir. ${ }^{9}$

Bu çalışmaya göre, $-(s) I(n)^{\prime} \mid$ ı bileşiklerdeki bu özel anlam -(s)I(n) ekine de yüklenemez, yani ekin işlevi iki ad arasında ilgi ilişkisi kurmak olamaz. Bunun nedeni de ilgi ilişkisinin -(s)!(n)'dan yoksun ortamlarda da var olmasıdır. §1'de gösterildiği gibi, bu ek üretken ad-ad bileşiklerinde zorunluyken, bu bileşikleri içeren kimi türetimlerde eklenememektedir, örneğin limon ağac*(-ı) ve limon ağaç(-*ı)-ıı bahçem. Bu iki biçimde de 'limon' ve 'ağaç' arasında aynı ilgi ilişkisi vardır ancak - $(s) I(n)$ yalnızca ilk yalın bileşikte eklenebilmekte, ikinci ifadede -Il eklenmesinden önce gelememektedir. $-(s) I(n)$ olmadığı halde bu anlamsal ilişkinin, iLGi'nin, korunması, açıkça, bileşiklerdeki ilgi iliş̧isinin -(s)I(n) ekine ya da eklenmesine yüklenemeyeceğini göstermektedir $\left(-(s) I(n)^{\prime}\right.$ ın işlevi için bkz. §3). ${ }^{10}$

Bu durumda ilgi işlevinin bileşikteki adlarla nasıl ilişkilendiğini açıklamak gerekir. Bunu açıklarken ilk seçeneğimiz, anlambilgisine üretici bir çerçeveden bakan, türe dayalı anlambilim modellerinin kullandığı (mantıkta da kullanılan) temel kurallar olabilir, örneğin İşlev Uygulama (İng. Functional Application: $f(x)$ ), bkz. Heim ve Kratzer, 1998). Ancak bu kural Frege'nin Tümleme İlkesi (İng. Principle of Compositionality) doğrultusunda sunulduğundan ve bir bütündeki anlamın, bütünün parçalarının anlamından oluştuğunu varsaydığından, bileşiklere, biçimsel olarak görünmeyen anlamsal öge (iLGi) sebebiyle bu haliyle uygulanamayacaktır: Bileşiklerde iki ögenin anlamına ek olarak bir de ilgi işlevi olduğunu hatrlayalım. Partee (1995), örneğin, bileşiklerdeki

9 Aynı şekilde, bu çalışmaya göre, gümüş (antika) bilezik, tahta (her) kapı, melek (bir) kadın, ingiliz (bir) avukat türünden yapılar da ayrılabilir olduklarından bileşik değil ad öbekleridir. Ancak bu tür ad öbeklerine iki ayrı şekilde yaklaşmak mümkündür: Bunları iki addan oluşan ve iLGi içermek yerine, örneğin eski bilezik öbeğindeki gibi sıfat ve addan oluşan AÖ'lerdeki gibi sıradan niteleme içeren AÖ'ler olarak değerlendirebiliriz. Ya da bu yapılardaki ilk ögeleri AÖ oluşumuna girmeden addan sıfat türeten biçimbilgisel bir dönüştürme/kayma işlemine (İng. conversion) girmiş ve sıfat ve addan oluşan AÖ'ler olarak değerlendirebiliriz. Her iki durumda da, bileşiklerin aksine, ad öbeğinde iki öge arası kurulan bir íLGi ilişkisi söz konusu değildir.

10 (İngilizce) Bileşiklerdeki ve ad öbeklerindeki farklı türden niteleme ilişkileri için bkz. Di Sciullo, 2009; Giegerich, 2009; Jackendoff, 2009. 
bu anlamın yukarıdaki tümleme ilkesine sorun oluşturduğunu ve tam olarak açıklanamadığını belirtmektedir (s. 337-338). Büyük olasılıkla yine bu sebepten, bazı araştırmacılar bileşiklerdeki bu özel anlamı edimbilimsel bağlamda anlık oluşan yorumlamalara yüklemektedir (bkz. Kay ve Zimmer, 1976; Downing, 1977; Spencer, 2011). Ancak bu çalışmalar, bileşiklerden çıkan bu yorumlamaların aslında belirli bir grup anlam ilişkisi altında toplandığını ve edimbilimsel bağlam izin vereceği halde bileşiklerde kullanılamayan ilişkilerin de var olduğunu gözden kaçırmaktadır.

Bu çalışmada "ilgi işlevleri" olarak tanımlanan üretken ad-ad bileşiklerindeki anlamsal ilişkiler bahar bademi örneğindeki gibi 'aitlik' ifade edebilir, ancak bu ilişki Türkçede karşımıza çıkan tek bir ilgi ilişkisi değildir. Bu çalışma, Kunduracı (2013)'e dayanarak, iLGi gibi iki üye arası genel bir ilgiye gönderme yapan bir ilişkinin yanında, daha özel ilgi ilişkileri olduğunu var saymaktadır. Ancak özelleşmiş de olsa bu daha özel ilişkiler de birer itgi tipidir. Bileşiklerdeki genel iLGi ilişkisini ve özelleşmiş alt ilişkilerini şu şekilde sıralamak ve örneklemek mümkündür (bkz. Kunduracl, 2013):
a. iLGi (genel): örn. para sorun-u
b. KAYNAK: salatalık süt- $\ddot{u}^{11}$
c. AMAÇ: çocuk bisiklet-i
Ç. YER: buz dans-I
d. Аітцік: yasemin koku-su
e. PARÇA-BÜTÜN: ${ }^{12}$ şeftali ağac-I
f. ARAÇ: telefon mesaj-ı
g. ÜYE-KÜME: ${ }^{13} 2$ sayI-SI
h. ETIKET: ${ }^{14}$ Yıldız Cadde-si

Bu çalışmaya göre, ad-ad bileşikleri ya en genel olan itgi'yi ya da onun daha özel çeşitleri olan yukarıdaki ilişkilerden birini, edimbilimsel bağlamın izin verdiği durumlarda birden çoğunu, içerebilir. Örneğin meyve şeker-i gibi bir bileşik, 'meyveye ait/meyvede bulunan şeker (fruktoz)' anlamıyla AiтLik, 'meyve için kullanılan (örneğin üstüne dökülen) şeker' anlamıyla AMAç, ve 'meyveden yapılan şeker' anlamıyla da KAYNAK ilişkisini içerebilir. Böyle bir durumda, kuşkusuz,

11 KAYNAK hem yukarıdaki örnekteki gibi somut hem de araba kirliliğ-i örneğindeki gibi soyut bir kaynak ilişkisi için kullanılabilir.

12 PARÇA-BÜTÜN ilişkisinde birincil, ya da içsel, bir tür içerme söz konusudur. Bu ilişkinin tersi yönündeki BÜTÜN-PARÇA, örneğin ağaç yapră̆-ı'ndaki gibi bir ilişki, yukarıda ayrı bir işlev olarak gösterilmemektedir. Bunun nedeni, BüTüNPARÇA ilişkisinin zaten yukarıda sırlanan AiтLik ilişkisi tarafindan içerilmesidir: Örneğin, ağaç yaprağ-ı 'ağaca Aiт bir tür yaprak'tan bahsetmektedir. Böylelikle, bu çalışmada ekonomiklik adına BÜTÜN-PARÇA, AiTLik ilişkisi altında değerlendirilmektedir.

13 Bu tür bileşiklerde ilk öge ikincinin oluşturduğu anlamsal bir kümenin üyelerinden biridir, örneğin '2', 'sayı' kümesine ait bir üyedir.

14 Bu tür bileşiklerde bağımlı öge baş ögenin adı olarak belirmekte ve bir etiketleme işlemi yapmaktadır. 
edimbilimsel bağlam yardımıyla hangi anlamın kastedildiğini kestirebiliriz. Ancak, bu çalışmaya göre bu durum, bileşiklerdeki anlamsal ilişkilerin edimbilimsel bağlam tarafindan oluştuğunu/ sağlandığını göstermemektedir. Bağlam, yalnızca birden çok ilişki olasıysa, istenilen ilişkiyi belirlemede etkilidir. Bu çalışmaya göre itgi işlevleri, edimbilimsel bağlam değil anlamsal bileşen tarafindan dil dizgesine sunulan anlamsal işlevlerdir. ${ }^{15}$

Burada savunulduğu gibi, Türkçede belli bir grup anlamsal ilişkinin bileşiklerde kullanıldığını destekleyen bir durum da Türkçedeki bileşiklerde kullanılamayan ilişkilerin var olmasıdır. Örneğin, sıradan ad öbeklerinde olan ve EşiTLEME olarak adlandırabileceğimiz, Türk doktor ya da yeni doktor gibi örneklerdeki ilişki, bileşiklerde kurulamamaktadır (burada bütünsel yapının anlamı hem 'doktor'a hem de 'Türk'e eşit derecede gönderme yapmaktadır: $x$ = 'Türk' ve $x=$ 'doktor' gibi). Bundan başka Benzerlik (ya da GiBi) ilişkisi de Türkçedeki bileşiklerde üretken biçimde kurulamıyor gibi görünmektedir, örneğin melek kadın örneğinde bu ilişki vardır, melek Giвi kadın, ancak bu yapı, yukarıda tartşılan benzer diğer ifadeler gibi, bileşik değil ad öbeğidir (ayrılabilir). Son olarak da ikiNciL içERME olarak tanımlayabileceğimiz, örneğin şeftalili pasta ifadesindeki -/l türetim ekiyle sağlanan ilişki, ad-ad bileşiklerinde görülmemektedir. Yukarıdan hatırlayacağımız gibi, bileşiklerdeki benzeri ifadelerde ya şeftali ağacı örneğindeki gibi PARÇA-BÜTÜN olarak tanımlanan birincil içerme ya da şeftali tatlısı örneğindeki gibi KAYNAK ilişkisi görülmektedir. şeftalili tatı ya da muzlu süt gibi ifadelerdeki ikinciL içERME ilişkisi ise, öyle görünüyor ki, Türkçede bileşik oluşumunda değil yalnızca -// türetimiyle mümkündür. ${ }^{16}$

Bu bölümde ad-ad tabanlı bileşiklerde kurulan özel anlamsal ilişkinin kaynağının anlambilimsel bileşen tarafindan dil dizgemize sunulan belli bir grup anlamsal işlev, iLGi işlevleri, olduğu önerilmiştir. ${ }^{17}$ Gelecek bölüm, bu işlevlerin Türkçede bileşim işlemine nasıl dahil olduğunu göstermektedir.

15 Bu işlevlerin sağladığı anlamların kimilerinin durum çekiminde ve işlevsel birimler olan ilgeçlerde de karşımıza çıkması, yukarıda da savunulduğu gibi, bağlama değil anlambilimsel bileşene ait olduklarını dolaylı yoldan

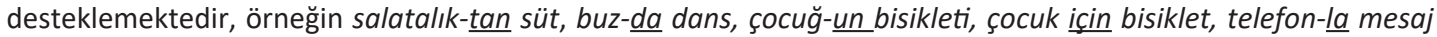
ifadelerindeki gibi.

16 Türkçenin aksine, bu ilişki örneğin İngilizcedeki bileşiklerde kullanılmaktadır, örn. banana milk. Bu da dillerin anlambilgisine ait ilişkileri farklı şekillerde kullanabileceğini göstermektedir.

17 Bileşiklerde iki öge arası kurulan bu tür ilişkiler, bu çalışmanın aksine, Levi'ye (1978) göre bileşiklerin altyapısında var olan sözdizimsel yapılardır ve Downing'e (1977) göre de edimbilimsel bağlam kaynaklıdır. Ancak şu noktaları vurgulamakta yarar vardır: Bileşiklerdeki anlamın sözdizimsel yapılarla benzeşmesi, örneğin kitap parası ve kitap için para ifadelerindeki gibi, yapısal değil anlamsal bir benzerliktir. Hem kitap parası bileşiğinde hem de kitap için para öbeğinde AMAç ilişkisi olması, bileşik yapısının da öbek yapısı gibi sözdizimsel bir işlemden geçmesini gerektirmez. Ayrıca yukarıda da değinildiği gibi edimbilimsel bağlam iLGi ilişkilerinin dil dizgesine sağlanmasından ve bunların adlarla anlamsal birleşiminden sorumlu olamaz, bunun için anlambilimsel, sistemli bir kurala gerek vardır, bkz. (§3). 


\section{Yapısal Çözümleme}

Bu bölüm Türkçede - $(s) I(n)$ içeren ad-ad tabanlı üretken bileşikler için süreçsel biçimbilim (Ing. Process(-based) Morphology) çerçevesinde, Kunduracı (2013)'e dayanan bir çözümleme sunmaktadır. ${ }^{18}$ Biçimbilgisine/biçimyapısına süreçsel yaklaşan bu gibi modellerde, ekler yalnızca biçimbilgisel birimler olarak değerlendirilir ve biçimyapısal işlemlere aittir. Diğer bir deyişle, eklerin sözlükçede girişleri ve sözdizimsel hiyerarşik yapıya ait konumları yoktur, örneğin bkz. Zwicky (1986), Aronoff (1994), Beard (1995), Pounder (2000), Stump (2001). ${ }^{19}$ Sunulan çözümleme aynı zamanda biçimyapısını, sözlükçeden, sözdizimden ve sesyapısından ayrı, ancak bu bileşenlerle yakın etkileşimler içinde olan özerk bir bileşen olarak kabul etmektedir, örneğin bkz. Zwicky (1986), Aronoff (1994), Beard (1995), Göksel (1998), Pounder (2000), Sadock (2012), Kunduracı (2013). Bu varsayımların ışığında, biçimyapısal işlemlerin daima sözdizimsel işlemlerden önce gerçekleşmesi gibi bir zorunluluk da yoktur: Gerektiği zaman önce, gerektiği zaman sonra devreye girebilir, ayrıca bkz. Lieber ve Scalise (2006), Kunduracı (2019a). ${ }^{20} \mathrm{Bu}$ varsayımlar doğrultusunda, ad-ad tabanlı bileşiklerin süreçsel çözümlemesi aşağıda Şekil 1'deki gibidir. ${ }^{21}$ Bu sistemde, Pounder (2000)'de olduğu gibi, <...> olarak gösterilen ve birbirinden ayrı (hatırlayalım, ayrıkık, Beard, 1995) biçimsel kurallar (BK), anlamsal kurallar (AK) ve ulamsal kurallar (UK) vardır; bu kuralların birbiriyle eşleşmesi biçimbilgisel işlemleri oluşturmaktadır. Bu da demektir ki biçimbilgisel bir işlem tek başına bir kuraldan daha karmaşıktır; aynı zamanda, işlemin uygulanabileceği taban türlerini belirleyen taban koşulları (TK) ve yine bu işlemlerin uygulanmasıyla ilgili bilgi içeren işlem koşulları (iK) içermektedir, bkz. Şekil 1:

$18-(s) !(n)$ içeren ad-ad bileşiklerinden sözlükçeye giriş yapan örnekler de vardır, hanım-el-i gibi. Bu çalışmaya göre, bu tür sözlükselleşmiş ifadeler de bu bölümde sunulan işlemlerin aynısından geçmekte, ancak, örneğin benzetmeye dayalı, ek bir anlamsal işlemden daha geçmektedir: yeni anlam edinme. Bu nedenle sözlükselleşmiştirler.

$19-(s)$ In) ekini ve bileşik yapısını sözdizimsel olarak değerlendirip çözümleyen çalışmalar için bkz. Dede, 1978; George ve Kornfilt, 1981; Kornfilt, 1984; Yükseker, 1994, 1998; Uzun, 2001; Bozşahin, 2002; Arslan-Kechriotis, 2006; Kharytonava, 2011.

20 Süreçsel ve özerk biçimbilgisi, bu açıdan Distributed Morphology (bkz. Halle ve Marantz, 1993) çerçevesi ile karıştırımamalıdır: Bu çalışmanın aksine, DM'de türetim, bileştirme ve çekimi içeren özerk bir biçimsel bileşen yoktur ve biçimbilgisi, sözdizim ilkeleriyle çalışan sözdizimsel bir alt bileşendir. Bu çalışma ise biçimyapısal bileşik türetimini sözdizimsel öbek türetiminden ayırmaktadır.

21 Bu sistemdeki işlemlerde anlam ve biçim arasında dolaylı bir eşleşme vardır, Jackendoff, 1975; Aronoff, 1994 ve özellikle Pounder'ın (2000) Process and Paradigm çerçevesinde olduğu gibi. 


\section{ADIM: BILEŞiM işLEMi}

$$
\begin{aligned}
& \text { AK: }\left\langle\text { ILGI }\left({ }^{\prime} x^{\prime}, ' y^{\prime}\right)>,\right. \\
& \text { BK: }\langle x+y=\{x-y\}>, \\
& \text { UK: }\langle A+A \rightarrow A> \\
& \text { Çıtt: badem-şeker }
\end{aligned}
$$

TK: A

IK: 2. Adıma geç!

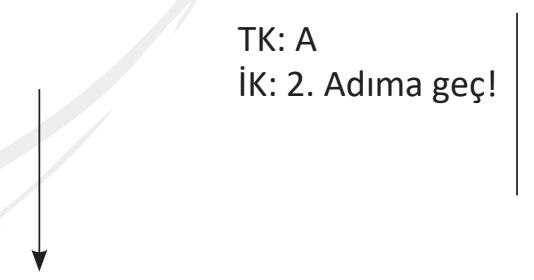

\section{ADIM: SÖZCÜK TÜRETME IŞLEMLERi}

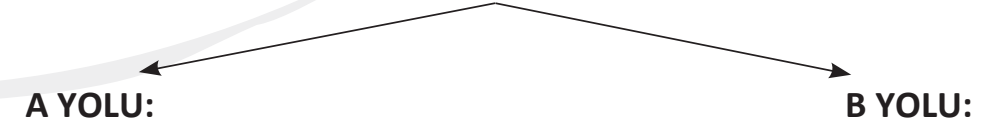

B 1. Seçenek:

$\begin{array}{ll}\text { AK: }\langle x \rightarrow \mathrm{x}\rangle, & \text { TK: A-A } \\ \text { BK: }\langle x+-(s) I(n) & \text { KK: } s \rightarrow \emptyset / \text { ünsüz }-> \\ \text { UK: }<A \rightarrow A> & \\ \text { Çıkt: } \text { badem-şeker-i } & \end{array}$

AK: < IÇERME (' $x$ ') $>$, TK: A, A-A

$\mathrm{BK}:\langle x+-\| />$

UK: $\langle\mathrm{A} \rightarrow \mathrm{S}>$

Çıkt: badem-şeker-li

B 2. Seçenek:

AK: <YOKSUN $\left({ }^{\prime} x^{\prime}\right)>$, TK: A, A-A

BK: $\langle x+-s / z>$

UK: $\langle\mathrm{A} \rightarrow \mathrm{S}\rangle$

Çıkt: badem-şeker-siz

\section{B 3. Seçenek:}
AK: < ILGILENEN (' $x$ ') >, TK: A, A-A
$\mathrm{BK}:\langle x+-\mathrm{Cl}>$
UK: $\langle A \rightarrow A>$
Çıkt: badem-şeker-ci

...

Şekil 1. Türkçede Ad-Ad Bileşik Tabanlı Sözcük Türetimi

Şekil 1'de 1. Adım Türkçede bileşik oluşumunu temsil etmektedir. Bu adımdaki anlamsal kural yukarıda §2'de anlatıldığı gibi bir ilgi işlevi ve bu işlevin uygulandığı iki üyeyi içerir: $f(x$, y). Burada önerilen anlamsal kural iki üye içerdiğinden geleneksel iş̧lev Uygulaması (bkz. §2) kuralından farklıdır. İşlev, örneğin, badem şeker-i gibi bir oluşumda uygulanıyorsa, KAYNAK olacak 
ve uygulandığı üyeler de bileşikteki iki ögenin anlamı olacaktır: 'badem' ve 'şeker'. Diğer bir deyişle, önerilen anlamsal kural şu şekildedir: KAYNAK ('badem', 'şeker'). ${ }^{22}$ Bu kuralın eşleştiği bir biçimsel bir de ulamsal kural vardır. Biçimsel kural iki ad tabanını birleştirmekle görevlidir:

$$
\mathrm{BK}:\langle x+y=\{x-y\}>
$$

Bu kuralla iki addan oluşan bir bileşik elde edilir: $\{x-y\}$ ya da $\{A-A\}$. Bu adımdaki son kural da, UK, girdi ve çıktı ulamlarıyla ilgili bilgilerden sorumludur, iki addan yine ad ulamında bir çıkt üretir:

$$
\text { UK: }\langle A+A \rightarrow A>
$$

Bu üç kuralın eşleşmesiyle (yani birlikte uygulanmasıyla) Şekil 1'de 1. Adım olarak temsil edilen ilk biçimsel işlem tamamlanmış olur. Ayrıca bu işlemin yalnızca ad türünden tabanlara uygulanabileceğini gösteren bir taban koşulu (TK) ve zorunlu olarak ardından 2. Adımdaki işlemin uygulanacağını gösteren bir de işlem koşulu vardır (IK). Bu ilk işlem sonucu üretilen çıkt bademşeker- gibi - $(s) I(n)$ içermeyen ancak iLGi ilişkisi içeren (yani 'bademden (yapılan)/kaynağı badem olan şeker' anlamı taşıyan) yalın, eklenmesiz bir bileşiktir.

Şekil 1'de ikinci adımda ise karşımıza öncelikle iki ayrı yol çıkmaktadır: A Yolu ve B Yolu. Bu durumda konuşucu hedeflediği anlama göre bir seçim yapmak durumundadır. Eğer 1. Adımda elde edilen çıktının (iıGi işlevli yalın bileşiğin) anlamında herhangi bir değişiklik istenmiyorsa A Yolu seçilerek, $-(s) I(n)$ ekinin eklenmesinden sorumlu işlem uygulanır ve sistemden badem şeker-i gibi bir çıktıyla ayrılınır. Bu işlemde AK: $<X \rightarrow X$ > olarak gösterilen bir anlamsal kural ve $<\mathrm{A}+\mathrm{A} \rightarrow \mathrm{A}>$ olarak gösterilen bir ulamsal kural vardır. Farkedileceği üzere, bu iki kural da (ilk adımdaki kuralların aksine) girdileri üzerinde herhangi bir değişiklik yapmayan özdeşlik (İng. identity) kurallarıdır. ${ }^{23}$ Ancak bu işleme ait biçimsel kural bir özdeşlik kuralı değildir:

$$
\text { BK: }<x+-(s) I(n), \text { KK: } s \rightarrow \emptyset / \text { ünsüz- }>
$$

Bu biçimsel kural 1. adımda üretilen yapıya -(s)।(n) ekini eklemekle görevlidir; bir de kural koşulu vardır, bu ekteki ünsüz, ek ünsüzlerle biten tabanlara eklenirken kullanılmamaktadır. ${ }^{24}$

22 Bu kural yerine bir alternatif olarak geleneksel anlamsal kural $f(x)^{\prime}$ i kullanarak, önce bileşikteki ilk elemana uygulayabilir, $\operatorname{KAYNAK('badem')~şeklinde,~ve~daha~sonra~da~yine~aynı~kuralı~kullanarak~çıktımız~ve~bileşikteki~}$ ikinci elemanı birleştirebilir ve anlamı temsil eden (ancak biçimle ilgisi) olmayan şu sonuca ulaşabiliriz: 'BADEMDEN('şeker'). Ancak bu durumda, bu alternatif anlamsal birleşmeyle, $f(x)$ kuralının ilk uygulanması sonucu elde edilen anlam üzerine Türkçede durum çekimini (bu örnekte ayrılma durumunu örneğin) ve sonucunda da bileşik yerine badem-den şeker gibi bir ad öbeği oluşumunu neyin engellediğini açıklamak gerekir. Bu sebeple Şekil 1'de, yukarıdaki geleneksel kural yerine, bileşikler için daha uygulanabilir görünen iki üyeli biçimi önerilmiştir.

23 Bu sebeple Pounder'a göre, bu kuralları " $X \rightarrow Y$ ve $X=Y$ ” şeklinde de göstermek mümkündür (2000: 68-69).

24 Burada biçimyapısına dayalı bir sesbilimsel değişiklik söz konusudur (yani biçim ve ses etkileşimi). Ancak bilindiği gibi biçimden bağımsız sessel koşullar da vardır, örneğin -(s)l(n) biçimindeki ünlü, eklendiği tabandaki son ünlüyle önlük/artlık ve yuvarlaklık açısından uyuşmak zorundadır. 
Bu üç kuraldan oluşan biçimyapısal işlemin taban koşulu, bu işlemin A-A türünden bir bileşiğe uygulandığını göstermektedir. İşlem sonucu elde edilen çıkt, \{badem şeker\}i gibi dilbilgisel bir sözcük oluşumudur. Bu çözümlemeye göre $-(s) I(n)$ ekinin bileşik göstericisi olmanın ötesinde, önemli bir görevi vardır: tek başına kullanılamayan bağımlı ad-ad bileşiklerinden, bkz. *limon ağaç-, *salatalık süt-, *badem şeker- vb., tek başına durabilen bağımsız sözcükler türetmek. Kısaca bu çalışmada $-(s) I(n)$, anlamsal değil yalnızca biçimyapısal bir işleve sahiptir: $-(s) I(n)$ türetimsel bir taban biçimleyicisidir, kısaca biçimcidir (Ing. (stem) formative). ${ }^{25}$

Eğer ilk adımın sonunda A yerine B Yolunu seçersek karşımıza birden çok seçenek çıkmaktadır. Bu seçenekler ilk adım sonucunda üretilen yalın bileşiklere $-(s) ı(n)$ yerine başka (türetimsel) ekler eklenmesini sağlamakta ve aynı zamanda yeni anlamlar katmaktadır. İlk seçenek -II ekinin eklenmesinden sorumlu biçimsel kuralı, BK: $\langle x+-\| l\rangle$, bu kuralla eşleşen ve girdinin anlamına ikincil bir içERME anlamının yüklenmesinden sorumlu anlambilimsel kuralı içerir: < içERME (' $x$ ') >. ${ }^{26}$ Bu kurallarla eşleşen ulamsal kural da addan sıfat oluşturmaktadır: UK: $<\mathrm{A} \rightarrow \mathrm{S}$ > . Işlemin taban koşulu (TK), bu işlemin hem basit ad tabanlarına, örneğin badem-li, şeftali-li gibi, hem de daha karmaşık tabanlara, örneğin A-A bileşiklerine, uygulanabileceğini, yani, -/l ekinin de - $(s)$ I(n) gibi A-A bileşiklerine eklenebilen bir ek olduğunu göstermektedir. İşlem sonucu elde edilen çıkt \{badem şeker\}li gibi tabanı ad-ad bileşiği olan türemiş bir yapıdır.

B Yolundaki ikinci seçenekte karşımıza -s/z ekinin eklenmesinden sorumlu biçimsel kural BK: $\langle x+-s / z\rangle$, bu kuralla eşleşen ve girdinin anlamına YoKSUN anlamının yüklenmesinden sorumlu anlambilimsel kural, < Y YKSUN (' $x$ ') >, ve bu kurallarla eşleşen, addan sıfat oluşturan UK: $<\mathrm{A} \rightarrow \mathrm{S}>$ kuralı çıkar. Bu ulamsal kural $\mathrm{B}$ yolunda ilk seçenektekinin aynısıdır. Bu işlemin taban koşulu (TK), yine bu işlemin hem basit ad tabanlarına, örneğin badem-siz, şeftali-siz gibi, hem de daha karmaşık tabanlara, yani A-A bileşiklerine uygulanabileceğini gösterir. Diğer bir deyişle, -s/z eki de -(s)I(n) ve -Il gibi A-A bileşiklerine eklenebilen bir ektir (krş. Kunduracı, 2013, 2019a). İşlem sonucu elde edilen çıkt, örneğin \{badem şeker\}siz, tabanı ad-ad bileşiği olan türemiş bir yapıdır. ${ }^{27}$

25 Türkçede taban biçimleme için bkz. Kunduracı (2019b).

26 Buradaki türetim işleminde §2'de bahsedildiği gibi PARÇA-BÜTüN ilişkisinde var olan birincil (içsel) içERME yerine ikincil türden bir içerme vardır, şeftali-li sözcüğündeki gibi. PARÇA-BÜTüN'deki birincil içERME, örneğin şeftali ağacı ifadesindeki gibi, bir bileşiğin oluşumunda ilk adımda gerçekleşen $f(x, y)$ kuralında dahil olacaktır.

27 Bu çalışmada önerilen $\{A-A\}+(s) I(n) / s / z / I I$ yapısı, taban biçim açısından, Schaaik'ın $(1996,2002)$ çözümlemesiyle paralellik göstermektedir. Benzer biçimde, $-(s) I(n)$, Göksel ve Haznedar'da da (2007) baş ad yerine A-A bileşiğine eklenmektedir. Türkçede bu gibi karmaşık tabanlar için bu çalışmayla paralel bir görüş için bkz. Uzun (1994, 2006, Varsayımsal Taban Önerisi). 
B yolundaki üçüncü seçenek ise $-\mathrm{Cl}$ ekinin eklenmesinden sorumlu biçimsel kuralı BK: < $x+-C l>$, bu kuralla eşleşen ve girdinin anlamına iLGiLENEN anlamının katılmasından sorumlu anlambilimsel kuralı, < iLGiLENEN $\left({ }^{\prime} x\right.$ ') $>$, ve bu kurallarla eşleşen, bu kez addan yine ad oluşturan, UK: $\langle A \rightarrow A>$, ulamsal kuralı içerir. Burada iLGiLENEN işlevi uygulandığı adın anlamına 'o adla bir şekilde ilgili kişi/varlık' anlamını katmaktadır, örneğin 'seven', 'üreten', 'satan', 'inceleyen' vb. $-\mathrm{Cl}$ eklenmesinin de dahil olduğu işlemin taban koşulu (TK), yine bu işlemin hem basit ad tabanlarına, örneğin badem-ci, şeker-ci gibi, hem de daha karmaşık tabanlara, yani A-A bileşiklerine uygulanabileceğini göstermektedir. Diğer bir deyişle, $-C l$ eki de $-(s) I(n),-/ l$ ve $-s / z$ gibi A-A bileşiklerine eklenebilen bir ektir (Kunduracı 2013, 2019a). İşlem sonucu elde edilen çıkt \{badem şeker\}ci gibi tabanı ad-ad bileşiği olan bir türevdir. ${ }^{28}$

- Cl ekiyle ilgili durum aslında göründüğünden daha karmaşıktr: -(s)I(n) içermeyen badem şekerci gibi biçimler gibi, -(s)I(n) içeren badem şekercisi gibi biçimlerin de dilbilgisel olması, yani -Cl'lı bileşiklerde bir ikililiğin olması, açıklama beklemektedir. Kunduracı (2013)'e dayanarak bu konuya şöyle bir açıklama önerilmektedir: badem şekerci gibi biçimler yukarıda gösterildiği ve aynen -(s)I(n), -II ve -s/z eklenmelerini içeren işlemlerde olduğu gibi, önce bir bileşik oluşması ve ardından da ilgili türetim ekinin bu A-A bileşiğine eklenmesi sonucu üretilir. Bu sebeple yukarıda Şekil 1'de sunulan ve bileşik oluşumunu izleyen işlemler arasında - $\mathrm{Cl}$ ekinden sorumlu işleme de yer verilmiştir (bkz. B 3. Seçenek). Ancak, örneğin badem şeker-ci-si gibi hem -Cl hem de -(s)I(n) içeren bir biçim bu şekilde çözümlenemez.

Bu çalışmaya göre iki eki de içeren bu ikinci tür biçim önce - $\mathrm{Cl}^{\prime}$ yla türetim işlemini ve türetimin ardından bileşim işlemini içermekte ve sonucunda da zorunlu olarak - $(s) !(n)$ ekini eklenmektedir: $\{\mathrm{A}\{\mathrm{A}-\mathrm{C} \mid\}\}-(s) I(n)$ şeklinde. Diğer bir deyişle, badem şeker-ci, badem şeker-li ve badem şeker-siz biçimlerinde -(s)I(n) olmamasının nedeni bu eklerin eklenme süreçlerinin, yani türetim işlemlerinin, aynen $-(s) I(n)$ süreci gibi, doğruca bileşik oluşumunu takip etmesidir, bkz. Şekil 1. Bunun aksine badem şeker-ci-si gibi bir biçimde türemiş bir yapı (şekerci) bileşik oluşumuna girdi oluşturmakta ve bileşen ögelerden birini oluşturmaktadır. Bu da demektir ki hem türetim bileşime girdi sağlayabilir, hem de bileşikler türetim işlemlerine girdi sağlayabilir. ${ }^{29}$

Şekil 1'deki dizge aslında Türkçede bileşim ve türetim işlemlerini içeren ve sözcük türeten bir dizil yapısıdır, türetimsel bir dizil. Bu yapıda üretken bir işlem olan (yalın) A-A bileşik oluşumunu ya $-(s) !(n)$ eklenmesinden sorumlu işlem ya da $-(s) !(n)$ yerine türetim ekleri ekleyen işlemler

28 -Cl'ı bileşik için diğer örnekler: cep telefon-cu, mercimek çorba-cı, buz paten-ci...

29 Kunduracı (2013)'ün, - $\mathrm{Cl}$ ekiyle ilgili araştırmasında $\{\mathrm{A}-\mathrm{A}\}-\mathrm{Cl}$ biçimi, araştırmaya katılan 25 Türkçe konuşucusunun $\% 78$ 'i, $\{\mathrm{A}\{\mathrm{A}-\mathrm{Cl}\}\}-(s) I(n)$ ise \%70'i tarafindan "düzgün ve kabul edilebilir" olarak değerlendirilmiştir. Bu da bize $\{A-A\}-C l$ biçiminin de en az $\{A\{A-C l\}\}-(s) I(n)$ kadar geçerli olduğunu göstermektedir. 
izlemektedir. Diğer bir deyişle, yukarıda (taban) biçimleyici olarak değerlendirilen - $(s)$ I(n), belli bir grup türetim ekiyle dizilsel bir karşıtlık ilişkisi içindedir ve - $(s) I(n)$ bu sebeple türetim eklerinin önünde belirememektedir. Yani, $\{A-A\}-(s) I(n)+-I I / s / z / C l$ yapısı bu sebeple dilbilgisidışıdır: *badem şeker-i-li, *badem şeker-i-siz, *badem şeker-i-ci gibi yapılar dilbilgisidışıdır ve bu çalışmaya göre bu durum bu eklerin benzer taban koşullarına bağlı dizilsel ilişkilerindendir. ${ }^{30}$ Şekil 1'de B yolundaki işlemlerin hepsindeki taban koşulları (TK), bu türetim eklerinin de A yolundaki -(s)I(n) gibi yalın A-A bileşiklerine eklenebildiğini göstermektedir. Bu, dizilsel süreçler arasındaki biçimsel ilişkidir.

Önemlidir ki, böyle bir dizil yapısı, sistemin çıktıları arasındaki yapısal ve biçimsel ilişkinin yanında, çıktılar arasındaki anlamsal ilişkiyi de açıklamaktadır: $-(s)$ I(n)’ı bileşiklerde iki öge arası kurulan anlamsal ilişki, yani i $\mathrm{LGi},-(s) I(n)$ yerine türetim eki içeren (B yolunda türetilen) çıktılarda da vardır. Diğer bir deyişle, badem şeker-i ifadesinde 'badem' ve 'şeker' arasındaki

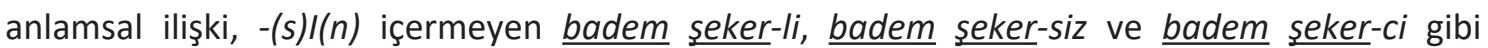
biçimlerde de vardır. -(s)ı(n) olsun olmasın, iki üye ('badem' ve 'şeker') arası ilişki oradadır. Bu durum açıkça, bu çalışmada savunulduğu gibi, $-(s) I(n)$ ekinin bileşiklerde anlamsal değil biçimsel bir işlevi olduğunu (biçimlemek) göstermektedir. Hatırlayalım ki Şekil 1'de bileşiklerde anlam süreci ve bileşim süreci ilk adımda, $-(s) I(n)$ eklenmeden önce gerçekleşmektedir. iLGi ilişkisini $f$ $(x, y)$ kuralıyla edinen bileşikler daha sonra girdi olarak ya $-(s) l(n)^{\prime}$ 'ı işleme ya da diğer türetim eklerinden sorumlu işlemlere girmektedir. Bu sebeple badem şeker-li, badem şeker-siz ve badem şeker-ci gibi biçimler -(s)I(n)'dan yoksun olsa da bileşikteki iki üye arası anlamsal ilişkiyi aynen taşımaktadırlar. Bu anlama ek olarak - $(s) I(n)$ 'sız türetimlerde, bu türetim işlemlerindeki ilgili anlamsal kuralların eklediği anlamlar da vardır tabii (bkz. Şekil 1).

Şimdi de, yukarıdaki durumun aksine, $-(s) I(n)^{\prime} l a$ birlikte belirebildiği türetim eklerine değinelim. Örneğin dağ keçi-cĭğ-i ve dağ keçi-lĭğ-i biçimlerinde -(s)I(n) ne yukarıdaki gibi türetim eklerinin önünde belirebilmekte, *dağ keçi-si-chik/lik, ne de yukarıdaki durumun aksine yerini bu eklere bırakabilmektedir. Bunun yerine, $-(s) I(n)$, eklerin ardından, zorunlu olarak eklenmektedir. $\mathrm{Bu}$ durum aslında $-\mathrm{Cl}$ ekini içeren yukarıda değinilen ikinci duruma benzerlik göstermektedir, badem şeker-çi-si gibi. Yani, -IIK-(s)I(n) ve $-C I K-(s) I(n)$ eklenmeli biçimleri de, öncelikle türetim ekleriyle türetim işlemine giren ve ardından keçicik, keçilik gibi türemiş çıktıların bileşim işlemine girdi olarak dahil olması ve sonucunda da $-(s)$ I(n) eklenmesiyle üretilen biçimler olarak açıklayabiliriz. - $C I K$ gibi bu ikinci türden türetim ekleri, basit $\mathrm{A}$ tabanlara eklenebilmekte ancak karmaşık A-A tabanlara, yani bileşiklere, eklenememektedir ve bu sebeple $-(s)$ I(n) ile herhangi

30 Kunduracı (2013)'ün araştırması -II, -s/z, -Cl gibi ad-ad bileşiklerine eklenebilen başka türetim ekleri olduğunu da ortaya çıkarmıştır, örn. \{buz mavi\}-msi'deki gibi -(I)ms/ ve \{pudra şeker\}-le'deki gibi -IE. 
bir dizilsel ilişki içine girememektedir, bkz. *dağ keçi-cik. Kısaca -(s)I(n), bütün türetim ekleriyle değil yalnızca belli bir grup ekle dizilsel bir ilişki içindedir: A-A bileşiklerine eklenebilen eklerle (örn. - II, -slz, -Cl). Bu tür tabansal özellikler, Şekil 1'deki gibi süreçsel yaklaşımlarda, biçimbilgisel işlemlerin taban koşullarına (TK) özerk biçimyapısı tarafindan atanır.

Bu bölümde tartışılanları şu şekilde özetlemek mümkündür: Türkçede ad-ad bileşiği oluşumu asıında türetimsel bir sözcük türetme dizgesinin bir parçasıdır. Bu dizge bir dizil yapısıdır, ad-ad bileşimini ve çıktı bileşiklerin girdi/taban olarak kullanıldığı belli bir grup türetimsel işlemi içermektedir (örn. -II işlemi). Ad-ad bileşiklerinde beliren -(s)I(n)'ın görevi anlamı etkilemeden sözcük türetmektir, dizilsel diğer türetim işlemlerinin $-(s) l(n)$ sürecinden farkı da anlamı etkileyerek sözcük türetmeleridir. -(s)I(n), dizilde işlemsel yeri olan diğer eklenmeler gibi bağımlı ad-ad bileşiklerinden bağımsız sözcük biçimleri üretmektedir. $-(s) I(n)$ olsun ya da olmasın, bu dizil yapısında üretilen tüm çıktılar şu yapıya sahiptir: $\{$ Ad-Ad\}+türetim eki. Bu şekilde karmaşık tabanlara eklenemeyen türetim eklenmeleri (örn. $-C I K)$ ise bu dizil yapısında $-(s) I(n)$ sürecine bir alternatif oluşturmamakta ve bu sebeple $-(s) I(n)$, bu eklerin ardından \{Ad +\{Ad-türetim eki\}\}+(s)।(n) biçiminde karşımıza çıkmaktadır. $-\mathrm{Cl}$ sürecindeki ikililik de yine bu iki farklı yapıyla açıklanabilir: Önce bileşim gerçekleşiyorsa çıkt $-(s) I(n)$ içermeyecek $\left(-I I^{\prime} \mid ı\right.$ ve $-s\left|z^{\prime}\right| ı$ süreçlerdeki gibi); ancak önce türetim sonra bileşim gerçekleşiyorsa çıkt - $(s) I(n)$ içerecektir (-CIK'lı süreçteki gibi). ${ }^{31} \mathrm{Ad}$-ad bileşiklerinin ve türetimsel süreçlerin yapısal ve anlamsal ilişkisini açıklayan ve $-(s) I(n)$ eklenmesine yalnızca biçimsel-türetimsel bir görev yükleyen bu çözümlemenin diğer çıkarımları ve getirileri aşağıda, §4’te tartışımaktadır.

\section{Diğer illginç Noktalar}

Bu bölümde, $-(s) I(n)$ eklenmesine (ve diğer eklenmelere) sözlüksel anlamlar yüklemeyen yukarıdaki gibi süreçsel bir yaklaşım sayesinde bileşikler ve $-(s)$ In)'la ilgili birkaç nokta daha çözümlenecek ve $\S 2$ ve $\S 3$ teki öneriler desteklenecektir. Bunlardan ilki ad-ad tabanlı bileşiklerin çoğul biçimidir: A-A-IAr-(s)I(n). Illk bakışta -(s)I(n) için yukarıda önerilen biçimseltüretimsel çözümlemeye karşıt gibi görünen bu durum, aşağıda göreceğimiz gibi, aslında önerilen çözümlemeyi destekler niteliktedir.

Dilbilgisel olan, limon ağaç-lar-ı gibi çokluk eki ve $-(s) I(n)$ içeren çoğul bileşikler ve dilbilgisidışı olan *limon ağaç-lar gibi $-(s) I(n)$ içermeyen ama bir çekim eki olan -IAr'ı

$31 \mathrm{Bu}$ ikililik yapısal farka dayandığı gibi konuşmacıya da dayanabilir: Kunduracı (2013)'ün araştırması bazı konuşmacıların çoğunlukla $\{A-A\}-C l$, bazı konuşmacıların çoğunlukla $\{A\{A-C l\}\}-(s)$ I(n) ve diğer bir grup konuşmacının da her iki biçimi de eşit olarak kullanmakta olduğunu göstermektedir. Bu durum - $\mathrm{Cl}$ sürecinin önerilen dizil yapısına -l/ ve -s/z süreçlerinden daha sonra dahil olduğuna işaret ediyor olabilir. 
içeren bileşikler $-(s)$ In) ekinin aslında türetimsel bir biçimleyici olduğu savını şu şekilde desteklemektedir. $-(s) I(n)$ eğer türetimsel değil de çekimsel bir ek olsaydı ${ }^{32},-(s) I(n)^{\prime} ı$ y yaptiğı işi, yani yukarıda önerildiği gibi bağımlı tabandan bağımsız biçim oluşturma işini, bir çekim eki olan -IAr'ın da yapabilmesini, dolayısıyla bu durumda -(s)I(n) eklenmesine gerek kalmamasını beklerdik. Ancak *limon ağaç-lar_ gibi $-(s)$ I(n)’sız çoğul bileşikler dilbilgisidışıdır. Örneğin İtalyancada adlar bağımlıdır, ama sayı ekleriyle, yani çekimle, birlikte bağımsızlaşırlar, bkz. * gatt 'kedi', gatt-o (kedi-TEK) 'kedi', gatt-i (kedi-çok) 'kediler'. ${ }^{33}$ Türkçede de (bu çalışmaya göre) ad-ad bileşikleri bağımlıdır ancak, italyancadaki durumun aksine, sayı ekiyle bağımsızlaşamamaktadır: *limon ağaç-lar, -(s)I(n) yine gereklidir. Bu da -(s)I(n)'ın görevini, §3’teki dizilsel işlemlere dahil olan türetim eklerinin yaptı̆ı̆ı, ancak bir çekim eki olan -IAr'ın yapamadığını göstermektedir. Aynı şekilde, Türkçede durum ekleri de bu görevi üstlenememektedir, yani -(s)I(n)'।ı bileşikler durum çekimine girdiğinde de -(s)l(n) yine gereklidir: bkz. limon ağac-ı- $a$ ve *limon ağac-a. Kısaca $-(s) l(n)$, ilginç bir şekilde, çekimsel değil türetimsel eklerle benzerlik göstermektedir: Aynı dizilde işlemsel bir yere sahiptir ve bu sebeple bu çalışmaya göre türetimsel bir görevle değerlendirilmektedir.

Ancak bu durumda çoğul bileşiklerde neden -IAr-(s)I(n) sırasının karşımıza çıkttğını ve *-(s)ı(n)-IAr'ın oluşamadığını açıklamak gerekir. Normalde bir türetim ekinin çekimden önce gelebilmesini beklerdik, Türkçedeki bu durumun aksine. Aslında bu sorunlu gibi duran durumun da şöyle bir açıklaması vardır: biçimbilgisel baş işlemi. Kunduracı (2013) bu durumda, Hoeksema'nın (1985) önerdiği baş işlemleri doğrultusunda, biçimsel bir tür baş işlemi olduğunu savunmaktadır. Yani Türkçedeki ad-ad tabanlı bileşiklerde sayı çekimi işlemi yalnızca bileşikteki başa uygulanmakta (taban olarak baş ögeyi hedef almakta) ve bu sebeple -IAr, $-(s) I(n)$ 'dan önce eklenmektedir. Bu şekilde sebebi belli olmayan herhangi bir silinme ya da yer değiştirme işlemine gerek kalmadan çoğul bileşik biçimleri rahatlıkla açıklanabilir. Bu aynı zamanda şu anlama gelmektedir: Türkçede ad-ad bileşiği oluşumunda, baş ögenin hemen ardında, -(s) I(n)'dan önce (çokluk eki için) bir konum ayrılmakta ve çoğul bir bileşik istendiğinde bu konum -IAr ile dolmakta, ve tekil bir bileşik durumunda da -IAr'sız, boş kalmaktadır. Kısacası türetimin çekimin dışında belirdiği bu gibi durumlar pek de beklenmedik değildir ve açıklanabilir. ${ }^{34}$

Diyelim ki bu baş işlemli yaklaşımı benimsemiyoruz, o zaman da bu durumu şöyle açıklardık. Adsıl sayı çekimi aslında, Booij'un $(1994,1996)$ önerisinde olduğu gibi, sözdizimsel yapıdan bağımsız bir tür çekimdir, yani içsel çekimdir (İng. inherent inflection). Bu sepeble adsıl

32 Örneğin Hayasi'ye (1996) ve Schaaik'a $(1996,2000)$ göre - $(s)$ II (n) çekim ekidir.

33 Italyanca örnekler Haspelmath ve Sims'ten alınmıştır (2010: 21).

34 Baş işlemleri ve türetimin çekimin dışında kalabildiği başka durumlar için ayrıca bkz. Zwicky, (1987a) ve Stump (1991). 
sayı çekimi, bağlama dayalı uyum ve durum çekimlerindeki gibi, sözdizimsel bağlamdaki yapıya dayalı çekimden (İng. contextual inflection) farklıdır ve Türkçede bileşiklerde bu gibi içsel bir çekimin sözcük oluşumu tamamlanmadan (biçimleyici -(s)I(n) sürecinden önce) uygulanması buradaki çözümlemelere sorun oluşturmamaktadır. Hatırlayalım ki, ayrıca, bu çalışmadaki varsayımlara göre biçim ve anlam ayrı düzlemlerdir ve bu durumda ek dizilimi, eklenmelerdeki işlevlerden bağımsız olarak, özerk biçimyapısının ayarladığı bir durumdur.

Şimdi de yine ilk bakışta sorunluymuş gibi duran bir başka durumu inceleyeceğiz: - $(s)$ $I(n)$ ekinin iyelik öbeklerindeki $-(s) I(n)$ ekiyle birlikte eklenememesi, yani yerleşik bileşik içeren iyelik öbeklerinde, odanın \{gül koku-su\}*-su gibi, bir iç tarafta bileşik için, bir de dış tarafta aitlik işlevi ${ }^{35}$ için $-(s) I(n)$ eklenememesi durumu. Bu durum hem bu çalışmadaki çözümleme, hem de iki yapıda da (bileşik ve iyelik öbeği) beliren -(s)I(n)'a ayrı işlevler yükleyen önceki diğer çalışmalar (bkz. §1) için olası bir sorundur çünkü normal şartlarda iki farklı görev için art arda iki $-(s) I(n)$ beklerdik.

odanın gül koku-su gibi ifadelerde iki $-(s) I(n)$ ’n mümkün olamaması, sessel bir kısıtlamadan ya da aynı işlevin tekrarlanmasını engelleyen anlambilimsel/işlevsel bir kısıtlamadan mı kaynaklanıyor diye bir soru gelebilir akıllara. Ancak, örneğin Haig (2004), Türçede bu gibi sessel ya da anlamsal/işlevsel kısıtlamalar olmadığını göstermektedir. Örneğin, siz-siz biçiminde sessel özdeşlik vardır ama biçim dilbilgiseldir; öl-dür-t- biçiminde de işlevsel özdeşlik vardır (iki ETTiRGEN) ama bu biçim de dilbilgiseldir (Haig,2004, örn. 17 ve 22). Yukarıda bahsedilen *-(s)I(n)-(s)I(n) engeli ise Haig'e göre hem sesbilimsel hem de işlevsel özdeşlik olduğu durumlarda uygulanan bir kısıtlamadandır. ${ }^{36} \mathrm{Bu}$ da bileşiklerdeki $-(s) I(n)$ ekinin iyelik öbeklerinde belirenle aynı işleve sahip olduğu anlamına gelmektedir.

Ancak bu çalışmada da varsayıldığı gibi, daha önceki kimi çalışmalar (örn. Hayasi, 1996; Bozşahin, 2002; Göksel, 2009; Kharytonava, 2011; Kunduracl, 2013) bileşiklerin ve iyelik öbeklerinin ve iki yapıda da karşımıza çıkan $-(s)$ I(n) ekinin farklı olduğuyla ilgili değiş̧ik noktalara değinmiştir zaten. Bu yaklaşımdan, yani -(s)I(n)’a iki işlev yükleyen yaklaşımdan, ayrılmadan da *-(s)I(n)-(s)!(n) sorununu çözmek mümkündür aslında. Bu izin verilmeyen ek dizisi için bu çalışmanın önerdiği çözüm şu şekildedir: Bu diziye izin vermeyen kısıtlama sesbilimsel ya da

35 gülün koku-su gibi iyelik öbeklerinde ait ögede bulunan -(s)I(n) bu çalışmaya göre, Kunduracı'nın $(2013,2015,2017)$ tartş̧th̆̆ gibi, herhangi bir kişi (' 3 ') ve sayı ('tek') değeri taşımamakta yalnızca 'aitlik, ait olma' (İng. possessedness) işlevi taşımaktadır; bu sebeple bu çalışmada aitlik işlevi (Aiт = İng. POss) olarak bahsedilmektedir. Bu çalışma ayrıca $-(s) ı(n)$ içeren bileşikleri biçimyapısal işlemlerin ürettiği sözcük oluşumları olarak değerlendirirken, iyelik öbeklerini, sözdizim ve biçimyapısının etkileşimleriyle oluşan sözdizimsel yapılar olarak değerlendirmektedir, bkz. Kunduracı $(2013,2017)$.

36 Türkçede bu gibi eklenme kısıtlamaları için ayrıca bakınız Kornfilt (1986). 
anlambilimsel/işlevsel değil biçimbilgisel/biçimyapısaldır. Bu biçimsel kısıtlama aynı biçimsel kuralın art arda uygulanmasını engellemektedir. Yani, §3'te Şekil 1'de 2. adımdaki $-(s) ı(n)$ eklenmesinden sorumlu işlemdeki biçimsel kural (BK), badem şeker-i gibi bir bileşikli türetimde kullanıldığı gibi, (onun) şeker-i yapısındaki gibi bir eklenmede de kullanılmaktadır (iyelik öbeklerindeki $-(s) l(n)$ süreci için bkz. Kunduracı, 2015). Bu ikinci durumda (iyelik öbeklerindeki çekimde), aynı biçimsel kural, BK: $<x+-(s) I(n)$, başka bir anlamsal kuralla eşleşmekte (AiтLik işlevi yükleyen) ve başka bir biçimyapısal işlemde kullanılmaktadır, ki bu işlem Şekil 1'dekinin aksine çekimsel bir işlemdir. Yani (gülün) koku-şu gibi bir biçimdeki $-(s) I(n)$, biçimsel olarak gül koku-şu gibi bir sözcük yapısındaki $-(s)$ I(n)’la aynıdır, aynı biçimsel kural uygulandığından ve ek bu kuralın bir parçası olduğundan. Ancak iki durumdaki biçimsel kuralın dahil olduğu işlemler ve işlemlerde eşleştiği anlamsal kurallar farklıdır: Türetimsel bileşik işleminde anlamsal 'özdeşlik' kuralıyla eşleşen -(s)I(n) sürecine (bkz. Şekil 1) karşın çekimsel işlemde anlamsal 'aitlik' kuralıyla eşleşen -(s)ı(n). Diğer bir deyişle, Türkçede izin verilmeyen durum aslında aynı biçimsel kuralın ikinci kez/art arda uygulanmasıdır. Bu sebeple, söz konusu kısıtlama sesbilimsel ya da anlambilimsel/işlevsel değil biçimbilgiseldir. ${ }^{37}$ Bu çözümleme hem iki ayrı ortamda eklenen -(s) I(n)'daki işlevsel farklılı̆ı korumakta hem de buna rağmen bu ekin yan yana eklenememesini açıklamaktadır. Bu çalışmada sık sık gönderim yapıldığı üzere, ayrıklığı yani anlam ve biçimin ayrı düzlemlere ait olduğunu benimseyen süreçsel bir yaklaşım yerine, bu eke (ve diğer eklere) kalıcı sözlüksel anlamlar ve sözdizimsel konumlar yükleyen bir yaklaşımla bu gibi biçimsel dizilim ve işlev örtüşmezlikler kolaylıkla çözümlenemezdi. ${ }^{38}$

Diğer bir soru da [evin \{gül kokusu\}] gibi baş konumunda bileşik içeren iyelik öbeklerindeki $-(s) I(n)^{\prime}$ ın hangi işleve sahip olduğudur: bileşiklerdeki türetimsel biçimleyici işlevi mi yoksa iyelik öbeklerindeki çekimsel aitlik işlevi mi. Bu çalışmaya göre bu karmaşık yapıda kullanılan biricik -(s) I(n) aitlik işlevine değil taban biçimleme işlevine sahiptir, yani Şekil 1'deki işlev. Diğer bir deyişle, [evin \{gül kokusu\}] gibi bir oluşumda, bileşim işlemini Şekil 1'deki gibi -(s)I(n) eklenme süreci izler ve $-(s)$ In)’ı sözcük türetimi gerçekleşir. Bu biçim, yukarıdaki gibi, bir iyelik öbeğinde baş olarak kullanıldığında da aitlik işlevi için gereken ikinci $-(s)$ I(n) yukarıda önerilen biçimbilgisel kısıtlama sebebiyle eklenemez; baş ögedeki (yukarıda gül kokusu) aitlik anlamı bağımlı ögedeki (yukarıda

37 Zwicky (1987b) benzer şekilde, İngilizcede sesbilimsel özdeşlik içeren dilbilgisel buśs ś 'otobüsün' gibi yapılarla anlamsal özdeşlik içermeyen ama biçimsel özdeşlik içeren dilbilgisidışı *kid-śs śs (çocuk-çoK-iıGi) 'çocukların' gibi biçimleri karşılaştırmakta ve yukarıda savunulduğu gibi bu durumu biçimsel kurallara dayalı biçimbilgisel özdeşliğe dayalı bir engele bağlamaktadır.

38 Aynı biçimsel kuralın, dolayısıyla aynı biçimbilgisel birimin, art arda uygulanmasını engelleyen yukarıdaki biçimbilgisel kısıtlama bir durumu daha açıklamaktadır: Baş konumunda bir bileşik içeren karmaşık bileşiklerde tek bir - $(s) I(n)$ olması, örneğin \{çocuk \{masal kitab\}-ı\} $\left.{ }^{*}-s ı\right)$. Bu çalışmada tartş̧ılmayan bu tür karmaşık bileşikler için bkz. Schaaik (2002). 
evin) sahiplik anlamından çıkarılabileceğinden herhangi bir anlamsal eksiklik ya da belirsizlik yaşanmaz. Ancak bağımlı ögenin olmadığı durumlarda, örneğin edimbilimsel bağlamın bu ögeyi gereksiz kıldığı durumlarda, [--- gül kokusu] gibi bir biçim bağlam dışında anlamsal belirsizliğe sahiptir: yalnızca 'gül kokusu' mu yoksa 'bir varlığın gül kokusu' mu. Bu da yukarıdaki çözümlemeye göre beklendik bir durumdur zaten. Aitlik işlevliyle örtüşen (çekimsel) -(s)l(n) ekinin (2a), türetimsel biçimleyici $-(s)$ I(n)'nın aksine (2b), günlük konuşmalarda eklenmeyebilmesi ve bileşik içeren iyelik öbeklerindeki -(s)।(n)'ın (2c), bu açıdan bileşiklerdekiyle benzerlik göstermesi, yani düşürülememesi de bileşik içeren iyelik öbeklerindeki $-(s) I(n)^{\prime} ı$ işlevinin türetimsel biçimleme olduğu savını desteklemektedir:

(2) a. evin manzara(-sı)

b. okyanus manzara*(-sı)

c. evin okyanus manzara*(-sı)

Bu savı destekleyen diğer bir nokta da bileşik içeren 1. ve 2. kişili iyelik öbeklerinde 1. kişi aitlik eki -(I)m ve 2. kişi aitlik eki -(I)n yerine, bir seçenek olarak -(s)I(n) ekinin eklenebilmesidir, bkz. (3):

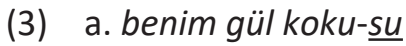
b. senin gül koku-su

(3)'teki ilginç durum yine bileşik içeren iyelik öbeklerindeki -(s)।(n)'ın çekimsel aitlik işlevi değil türetimsel biçimleyici işlevini taşıdığını göstermektedir: 1 . kişi aitlik eki -(I)m ve 2 . kişi aitlik eki -(I)n ile çekimsel bir dizil ilişkisi içinde olan aitlik işlevli $-(s) I(n)^{\prime} ı n,-(I) m$ ve $-(I) n$ yerine aynı anlamla oluşmasını bekleyemeyiz, bkz. (4):
(4) a. 'şeker-im' $\neq$ 'şeker-i'
b. 'şeker-in' \# 'şeker-i'

Bu da demektir ki, (3)'teki türden biçimlerde, bileşik oluşumunu Şekil 1'deki gibi -(s)।(n) eklenme süreci izlemekte ve sonuç olarak -(s)I(n)'lı sözcük türetimi gerçekleşmektedir (gül kokusu). Bu biçim, 1. ve 2. kişi içeren bir iyelik öbeğinde baş olarak kullanılabilmektedir; baş ögedeki (yukarıda gül kokusu) aitlik anlamı bağımlı ögedeki (yukarıda benim/senin) sahiplik bilgisinden (1. kişi ben ve 2. kişi sen'den) çıkarılmaktadır. Kısaca, bu çalışmaya göre, örneğin Kornfilt (1986)'nın 
aksine, $-(s) I(n)$ ekinin art arda eklenemeyişi yalnızca biçimbilgisiyle ilgili bir durumdur. Kornfilt (1986), -(s)।(n)'ın bileşiklerde de iyelik öbeklerinde de kişi+uyum işlevi olduğunu ve *-(s)I(n)(s)।(n) diziliminin bu işlevsel-ulamsal benzerlikten ötürü kullanılmadığnı ileri sürmektedir (bkz. Kornfilt'in Stuttering Prohibition olarak adlandırdığı yasağı). Oysaki bu çalışma, Kunduracı (2013, 2017)'de olduğu gibi, öncelikle, -(s)I(n) ekinin (i) bileşiklerde UYUMdan ya da Kişíden sorumlu olamayacağını, (ii) iyelik öbeklerinde de Kişi değil yalnızca iYElikten/AiTlikten sorumlu olduğunu (iii) bileşik içeren iyelik öbeklerinde de bileşiklerdeki işleviyle eklendiğini göstermekte ve (iv) sorunlu *-(s)I(n)-(s)I(n) diziliminin sessel ya da işlevsel değil saf biçimbilgisel/biçimyapısal bir engelden izin verilmediğini savunmaktadır. ${ }^{39}$

Son olarak açıklanması gereken ve bu çalışmadaki öneri ve savlara meydan okurcasına karşımıza çıkan durum da türetimsel biçimleyici $-(s)$ I(n)'ın kişi-aitlik ekleriyle yani 1. kişi aitlik $-(I) m$ ve 2 . kişi aitlik -(I)n ekleriyle, beklenenin aksine, örneğin (3)'teki gibi ifadelerde art arda eklenememesidir, bkz. (5):

(5) a. (benim) *gül koku- $\underline{\text { su}} \underline{\underline{m}}$

b. (senin) *gül koku- $\underline{s u} \underline{-n}$

Üstelik bu durumda yukarıda *-(s)I(n)-(s)I(n) dizisinde olduğu gibi biçimbilgisel, işlevsel ya da sesbilimsel bir engel de öne sürülemez: Açıkça görevler, biçimler ayrıdır. Ancak biçimbilgisel sistemin işlemlere atadığı taban koşullarına dayanan bir açıklama önerilebilir: (5)'teki gibi yapılarda biçimleyici -(s)I(n)'ın beklendiği halde -(I)m ve -(I)n'dan önce eklenememesi ya da (3)'te olduğu gibi -(I)m ve -(I)n'ın -(s)I(n)'dan sonra eklenememesi bu eklerle -(s)I(n)'ın taban koşulları açısından gösterdiği benzerliktir. Bu ekler de aynen -(s)।(n) ve §3’te Şekil 1'de -(s)I(n)'la dizilsel bir ilişki içinde olduğu önerilen türetim ekleri gibi yalın A-A tabanlara eklenebilmektedir (diğer tabanların yanında). Burada $\S 3$ 'tekinden farklı olan durum, $-(I) m$ ve $-(I) n$ eklenme süreçleriyle sözcük oluşumu/türetimi değil sözcük çekiminin gerçekleşmesidir, $-(I) m$ ve $-(I) n$ aitlik+kişi eki olduğundan. ${ }^{40}$ Bununla beraber, öyle görünüyor ki bu eklerin çekimsel olması bu eklerin A-A tabanlarına eklenmesine herhangi bir engel oluşturmamakta ancak aitlik-kişi eklerini, taban koşulları açısından, diğer adsıl çekim ekleri (durum ve sayı) arasında özel kılmaktadır. ${ }^{41}$

39 Bu savın aksine, Hayasi (1996) bu karmaşık yapıdaki -(s)I(n)'a iyelik (+kişi) işlevi, Bozşahin (2002) ise bu yapılardaki $-(s) I(n)$ 'a hem iyelik (+kişi) hem de bileşik gösterme işlevinden oluşan birleşik bir işlev yüklemektedir.

40 Kunduracı $(2013,2015,2017)$ "Kişi" gibi "Aitliğ"in de Türkçede alt değerleri olan (+/- gibi) bir dilbilgisel ulam olduğunu tartışmaktadır.

41 Burada konuşucularda bir öngörü ve dinleyicilerde bir önsezi olduğunu öne sürmek de mümkün görünmektedir: 1./2. kişi-aitlik eklerinin ekleneceği durumlarda bu eklerin ekleneceğini öngörmek ve $-(s) I(n)$ ekini öncesinde eklememek gibi. 
Bu bölümde tartş̧ınlar şöyle özetlenebilir: Çokluk ve durum çekimli ad-ad bileşiklerinde çekim eklerine rağmen $-(s) I(n)$ ekinin zorunlu olması bu ekin bağımlı tabanlardan bağımsız biçimler türeten bir biçimleyici olduğu önerisini destekler niteliktedir. -(s)I(n)'ın, bu durumun aksine, bileşik içeren iyelik öbeklerinde aitlik işlevi için ikinci kez eklenememesinin $\left({ }^{*}-(s) !(n)-\right.$ $(s) I(n))$, biçimbilgisine ait bir $-(s) I(n)$ biçiminin, yani bu eki ekleyen bir tane biçimsel kuralın, olmasından ve bu kuralın hangi işlev gerekirse gereksin, yani hangi anlamsal kuralla eşleşirse eşleşsin, ikinci kez uygulanmasına izin vermeyen saf biçimsel bir engelden kaynaklandığı önerildi. $-(s) I(n)$ 'ın 1./2. kişi-aitlik ekleriyle birlikte eklenmemesi ise $\left({ }^{*}-(s) I-m / n\right)$ süreçsel eklenmelerdeki taban koşullarıyla, yani bu eklerin de -(s)I(n) (ve kimi türetim ekleri) gibi yalın ad-ad bileşiklerine eklenebilen türden ekler olmasıyla açıklandı.

\section{Sonuç ve Öneriler}

Bu çalışmada Türkçede - $(s) I(n)$ içeren ad-ad tabanlı bileşiklere yapısal ve anlamsal bir çözümleme sunulmuştur. Bu çözümlemeyle hem -(s)I(n) ekinin bu bileşiklerde neden gerektiği hem de bu bileşiklere dayalı belirli ortamlarda neden eklenmediği açıklanmıştır. Çalışma -(s) I(n)'।ı bileşik oluşumunu ve -(s)I(n)'ın eklenmesini Türkçede sözcük türetiminden sorumlu bir dizil yapısının belirli kısımları olarak değerlendirmiştir. Bu dizilde bileşik oluşumu (bileşim işlemi) $-(s) I(n)$ içermemekte ve $-(s) I(n)$ eklenmesi bileşim işlemini izleyen belirli türetimsel seçeneklerden biri olarak sunulmuştur. Ayrıca çalışmaya göre $-(s)$ I(n)'ın görevi anlamsal değil biçim(bilgi)sel/biçimyapısaldır.

Çalışmada sunulan türetimsel dizil yapısı aynı zamanda bileşiklerdeki - $(s)$ I(n)'ın çekimsel bir ek olmadığı yönünde çıkarımlar yapmamızı sağlamış ve süreçsel biçimbilim modellerinde varsayılan anlam ve biçim eşleşmelerini kullanarak ayrı işlevlere sahip iki $-(s)$ I(n)'ın yan yana neden oluşamadığını ve yine bu modellerde biçimbilgisinin vazgeçilmez birimleri olan taban koşullarını kullanarak, $-(s)$ (n)'ın neden kişi-aitlik ekleriyle birlikte eklenemediğini açıklamıştır.

Bunlardan çıkaracağımız ilk sonuç biçimbilimde biçim ve anlamı ayrı ayrı değerlendiren süreçsel yaklaşımların dilbilgisel birimlere akla yatkın çözümlemeler getirebildiğidir (örneğin nedensiz yer değiştirme, silinme ya da bulunduğu konumdan başka bir yerde algılanma gibi süreçlere başvurmayan çözümlemeler). Diğer bir sonuç da normalde anlam ve biçimin bire bir eşleştiği eklemeli bir dil olan Türkçede de yalnızca biçimle ilgili görevi olan eklerin görülebildiğidir (ayrıca bkz. Kunduracı, 2019b). Bağımlı biçimlerden (yalın A-A bileşikleri) bağımsız biçimler (bileşik tabanlı türevler) üretebildiği için bileşiklerdeki -(s)ı(n)'ın türetimsel değerlendirilmesi de diğer bir sonuçtur. Sözlükçede yer edinemeyen yalın ad-ad bileşikleri -(s) I(n) sayesinde sözlükçede yer edinebilir duruma gelmektedir, yani aday sözlükbirim olmaktadır. 
Bu noktada -(s)I(n)'ın aynen - II, -slz, -Cl (ve benzeri birkaç ek daha, bkz. Kunduracı 2013, 2019a) gibi davrandığını hatılamakta yarar vardır. Tüm bu ekler A-A tabanlarına eklenebilen ve sözcük türetebilen eklerdir.

Ancak bu taban türüne, $\{A-A\}$, eklenebilen iki ek daha vardır ki bu ekler çekimseldir: kişiaitlik ekleri -(I)m ve -(I)n. Bu iki ek türetim yerine çekim işlemlerinin elemanı olduğundan nasıl olup da türetim ekleri gibi yalın ad-ad bileşiklerine eklendikleri yeni bir soru işareti olabilir ve türetim-çekim bağlantılarına odaklanan gelecek çalışmalar bu konuya eğilerek, örneğin aitlik eklerinin tarihsel gelişimini inceleyerek, bu konuya aydınlık getirebilir. Kimi dillerde aitlik ekleri durum eki olarak, kimi dillerde çekimsel değil türetim eki olarak karşımıza çıkabilmektedir. Türkçede de bu eklerin tarihsel gelişiminde bir tür tür değişiminin olup olmadığına bakmak yararlı olacaktır. Tarihsel araştırma gerektiren bir başka nokta da Türkçede neden hem bileşiklerin hem de sahip ögesi 3. kişi olan iyelik öbeklerinin farklı işlevlere rağmen baş ögede aynı biçimi, $-(s)$ I(n) eklenmesini, içerdiğidir. Bu alanda bir öneri için bakınız Kunduracı (2017).

Bunların dışında çalışmada değinilmeyen, bileşik gibi görünen ve yine iki ad türünden oluşan abla-kardeş gibi birleşik yapılar ve şair-yazar gibi eşlemeler de vardır; ancak bu yapıların da bileşik olduğunu ya da olmadığını (örneğin bileşik yerine sözdizimsel yapılar olduğunu) savunmak için ayrı bir çalışma gerekir. Bu çalışmadan gelecek çalışmalara yöneltilebilecek soru, bu yapıların bileşik olarak değerlendirilmesi durumunda, neden bunlarda biçimleyici -(s)।(n)'ın eklenmediğidir. Örneğin, bileşik oluşumunu izleyen sözcük türetimleri yalnızca bileşiğe belli bir anlamsal kural uygulandığında mı ( $\$ 3^{\prime}$ te sunulan iki üyeli anlamsal iLGi işlevi) zorunlu hale gelmektedir? Yani, yalnızca iLGi yüklenen bileşikler mi Türkçede bağımlı A-A biçimleri olarak karşımıza çıkmaktadır?

Anlamla ilgili diğer bir soru da güneş batması gibi eylemcil birimi olan ad-ad bileşiklerindeki anlamsal düzlemdir. Bu çalışmaya göre, bu tür bileşikler de Şekil 1'deki dizgenin çıktısıdır ve yapısal olarak ayrı bir çözümleme gerektirmez: \{güneş batma\}sı 'güneşe Aiт batma'. Ancak öyle görünüyor ki bu gibi eylemcil birimli bileşiklerde, eylem kökündeki sözlüksel üye konumunun, bileşiğin ilk ögesinin anlamıyla doldurulduğu anlamsal bir düzlem daha vardır. Bu durumda hem (anlamsal) yüklem-üye ilişkisinin kurulduğu hem de bileşim sırasında iLGi'nin yüklendiği bir anlamsal düzlem olduğunu düşünebiliriz. Ya da yüklem-üye ilişkisi için böyle ayrı bir düzlem atamadan, bu ilişkiyi edimbilimsel ortamdan çıkarabiliriz, şeklinde düşünebiliriz. Bu durumu da, eylem tabanlı A-A bileşiklerine odaklanan gelecek çalışmalarda netleştirmek yararlı olacaktır.

Son çıkarımımız da alanyazınında çoğunlukla çekimsel ilişkiler için sunulan ve genellikle durağan sözcük biçimlerinden oluşan dizil yapılarıyla ilgili olacaktır. Bu çalışma dizil yapılarının yalnızca çekim değil türetim ve bileşim süreçlerini de yakından ilgilendirdiğini ve dizillerin 
sözlükçeyle kısıtlı durağan değil biçimyapısına ait devingen yapılar olduğunu göstermektedir. Şekil 1'de sunulan dizgedeki yapı her aşamasında üretken işlemler içermektedir. Dizile zaman içinde yeni işlemler de dahil edilebilir, örneğin Orhun Türkçe-ci-si ifadesini kullanan, yani - $\mathrm{Cl}$ ve $-(s) l(n)$ eklenmelerini dizilsel bir ilişki içermeden, art arda kullanabilen bir konuşmacı zaman içinde $-\mathrm{Cl}$ eklenmesini de A-A bileşiklerine ekleyerek $-(s) I(n)$ ile dizilsel bir ilişkiye sokabilir ve Orhun Türkçe-ci gibi ifadeleri kullanır duruma gelebilir. Ya da aynı konuşucu farklı ortamlarda farklı yapıdaki ifadeleri kullanabilir, örneğin aynı anlam için dizilsel ilişkiyi kullanarak \{Orhun Türkçe\}-ci diyebilir ya da kullanmayarak \{Orhun \{Türkçe-ci\}\}-si diyebilir. Tüm bu durumlar yine dizil yapılarının devingenliğini göstermektedir. Çıktılar sözlükçeye gönderilebilir ancak bu her çıktının sözlükçeye gönderileceği ya da dizgedeki işlemlerin sözlükçede gerçekleştiği anlamına gelmemektedir. Bu dizge, özerk ve üretici biçimbilgisine/biçimyapısına ait bir birimdir.

Biçimyapısal işlemlerin sözlükçede gerçekleştiğini varsaydığımızda bu işlemlerin girdilerini sözlükçeyle kısıtlamak durumunda kalırdık ve örneğin §1'de bahsedilen öbekli bileşikleri açıklayamazdık. \{[yeşil elma] ağac\}ı gibi bir ifade, kuşkusuz, sözdizimsel bir birim

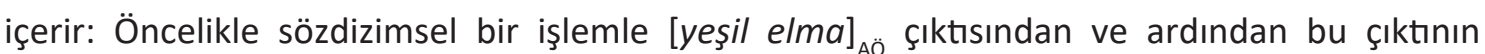
bileşik işlemine bir girdi olarak alınması ve ikinci öge ağaç ile bileşmesinden oluşur. ${ }^{42}$ Bileşim ve sözcük türetimlerini sözlüksel süreçler olarak değerlendirmek bu gibi yapılardaki olası sözlüksel süreçler öncesi gerçekleşen sözdizimsel süreçleri özellikle, Sözlüksel Bütünlük İlkesi (bkz. §1) sebebiyle açıklayamaz. Diğer bir yönden, bileşik oluşumunu (ve diğer biçimbilgisel süreçleri) sözdizimsel süreçlerle eşit tutmak da bileşikler (ve diğer biçimbilgisel çıktılar) ve öbekler arasındaki açık farklılıkları akla uygun bir şekilde açıklayamamaktadır. Örneğin, hem gül kokusu gibi bir bileşik sözcüğü hem de gülün kokusu gibi bir öbeği sözdizimsel çıkt olarak değerlendirmek iki yapı arasındaki son derece açık benzeşmezlikleri (bkz. §1) ve bunların olası nedenlerini yok saymak anlamına gelir. Akıllara da doğrudan şöyle bir soru gelir: İki yapı da sözdizimselse, Türkçe neden ikisini de farklı biçimsel ve gönderimsel özelliklerle sunmaktadır? Bu sebeplerle, bu çalışma biçimbilgisini/biçimyapısını sözlükçe, sözdizim, anlambilgisi ve sesçil yapıdan ayrı ancak bu bileşenlerle etkileşim içinde olan, sözdizimsel süreçlerden önce olduğu gibi sözdizimsel süreçlerden sonra da işlem gerçekleştirebilen (Kunduracı 2013, 2019a, 2019b), özerk bir dizge olarak değerlendirmiş; Türkçede bileşik ekini bir biçimleyici olarak sunmuş ve bu ekin eklenme/eklenememe süreçleriyle biçimsel özerkliği göstermeyi hedeflemiştir.

42 Türkçede bundan daha büyük ve karmaşık öbekler içeren bileşikler için bkz. Göksel (2015). 


\section{Kaynakça}

Anderson, S. R. (1982). Where is morphology? Linguistic Inquiry (13), 571-612.

Anderson, S. R. (1992). A-morphous morphology. Cambridge: Cambridge University Press.

Aronoff, M. (1994). Morphology by itself: Stems and inflectional classes. Cambridge: MIT.

Arslan-Kechriotis, Z. (2006). Case as an uninterpretable feature (Doktora Tezi). Boğaziçi University.

Aslan, E. ve Altan, A. (2006). The role of -(s)I in Turkish indefinite noun compounds. Dil Dergisi (131), 57-76.

Baker, M. (1998). Comments on the paper by Sadock. S. Lapointe, D. Brentari ve P. Farrell (Yay.), Morphology and its relation to phonology and syntax, (ss. 188-212). Standford: CSLI Publications.

Beard, R. (1995). Lexeme-morpheme base morphology. Albany: State University of New York Press.

Blevins, J. (2001). Paradigmatic derivation. Transactions of the Philological Society (99), 211-222.

Booij, G. (1994). Against split morphology. G. Booij ve J. van Marle (Yay.), Yearbook of morphology 1993, (ss. 27-50). Dordrecht: Kluwer.

Booij, G. (1996). Inherent versus contextual inflection and the Split Morphology Hypothesis. G. Booij ve J. van Marle (Yay.), Yearbook of Morphology 1995, (ss. 1-16). Dordrecht: Kluwer.

Borer, H. (2009). Afro-Asiatic, Semitic: Hebrew. R. Lieber ve P. Štekauer (Yay.), The Oxford handbook of compounding, (ss. 491-511). Oxford: Oxford University Press.

Bozşahin, C. (2002). The combinatory morphemic lexicon. Computational Linguistics (28), 145-186.

Carstairs-McCarthy, A. (1998). Paradigmatic structure: inflectional paradigms and morphological classes. A. Spencer ve A. M. Zwicky (Yay.), The handbook of morphology, (ss. 322-334). Oxford: Blackwell.

Dede, M. (1978). A syntactic and semantic analysis of Turkish nominal compounds (Doktora Tezi). University of Michigan.

Di Sciullo, A. (2009). Why are compounds a part of human language? A view from Asymmetry Theory. R. Lieber ve P. Štekauer (Yay.), The Oxford handbook of compounding,(ss. 145-177). Oxford: Oxford University Press.

Downing, P. (1977). On the creation and use of English compound nouns. Language (53), 810-842.

George, L. ve Kornfilt, J. (1981). Finiteness and boundedness in Turkish. F. Heny (Yay.), Binding and Filtering, (ss. 104-127). London: Croom Helm; Cambridge, Mass: MIT.

Giegerich, H. J. (2009). Compounding and lexicalism. R. Lieber ve P. Štekauer (Yay.), The Oxford handbook of compounding, (ss. 178-200). Oxford: Oxford University Press.

Göksel, A. (1998). Word size. G. Booij, A. Ralli ve S. Scalise (Yay.), Proceedings of the first Mediterranean conference on morphology, (ss. 190-200). Patras: University of Patras.

Göksel, A. (2009). Compounds in Turkish. Lingue e Linguaggio (2), 213-236.

Göksel, A. (2015). Phrasal compounds in Turkish: Distinguishing citations from quotations. C. Trips ve J. Kornfilt (Yay.), Phrasal Compounds (Language Typology and Universals, STUF 68.3), (ss. 359-394). Berlin: De Gruyter.

Göksel, A. ve Kerslake, C. (2005). Turkish: A comprehensive grammar. London: Routledge.

Göksel, A. ve Haznedar, B. (2007). Remarks on compounding in Turkish. 14. 10. 2018, http://componet. sslmit.unibo.it/download/remarks/TR.pdf 
Guilbert, L. (1975). La créativité lexicale. Paris: Larousse.

Haig, G. (2004). Constraints on morpheme repetition in Turkish? K. Imer ve G. Dogan (Yay.), Current Research in Turkish Linguistics, (ss. 3-12). Gazimagusa: Eastern Mediterranean University Press.

Halle, M. ve Marantz, A. (1993). Distributed Morphology and the pieces of inflection. K. Hale ve S. J. Keyser (Yay.), The view from building 20, (ss. 111-176). Cambridge, MA: The MIT Press.

Harley, H. (2009). Compounding in distributed morphology. R. Lieber ve P. Štekauer (Yay.), The Oxford handbook of compounding, (ss. 129-144). Oxford: Oxford University Press.

Haspelmath, M. ve Sims, A. D. (2010). Understanding morphology, 2nd edn. London: Hodder Education.

Hayasi, T. (1996). The dual status of possessive compounds in Modern Turkish. Á. Berta, B. Brendemoen ve C. Schönig (Yay.), Symbolae Turcologicae 6, (ss. 119-129). Swedish Research Institute in Istanbul: Uppsala.

Heim, I. ve Kratzer, A. (1998). Semantics in generative grammar. Oxford: Blackwell.

Jackendoff, R. (1975). Morphological and semantic regularities in the lexicon. Language (51), 639-671.

Jackendoff, R. (2009). Compounding in the Parallel Architecture and conceptual semantics. R. Lieber ve P. Štekauer (Yay.), The Oxford handbook of compounding, (ss. 105-128). Oxford: Oxford University Press.

Kay, P. Ve Zimmer, K. (1976). On the semantics of compounds and genitives in English. 6th California Linguistics Association proceedings, (ss. 29-35). San Diego: San Diego State University Press.

Kharytonava, O. (2011). Noms composés en Turc et morphème -(s)I (Doktora Tezi). The University of Western Ontario.

Kornfilt, J. (1984). Case marking, agreement, and empty categories in Turkish (Doktora Tezi). Harvard University.

Kornfilt, J. (1986). The stuttering prohibition and morpheme deletion in Turkish. E. Erguvanli-Taylan ve A. Aksu-Koç (Yay.). Proceedings of the Turkish linguistics conference, (ss. 295-307). İstanbul: Boğaziçi University Publications.

Kunduracı, A. (2013). Turkish noun-noun compounds: A process-based paradigmatic account (Doktora Tezi). University of Calgary.

Kunduracı, A. (2015). Türkçede aitlik ulamı ve biçimsel ifadesi. Dilbilim Araştırmaları Dergisi 26 (1), $43-62$.

Kunduracı, A. (2017). Process Morphology in concatenation. N. Büyükkantarcıoğlu, I. Özyıldırım ve E. Yarar (Yay.), 45. Yıl Yazıları, (ss. 255-278). Ankara: Hacettepe Üniversitesi Yayınevi.

Kunduracı, A. (2019a). The paradigmatic aspect of compounding and derivation. Journal of Linguistics, 55 (3), 563-609.

Kunduracı, A. (2019b). Saltbiçim işlemleri ve taban biçimleme. Dilbilim Araştırmaları Dergisi, 30 (2), 199219.

Lapointe, S. G. (1980). The theory of grammatical agreement (Doktora Tezi). University of Massachusetts, Amherst.

Levi, J. (1978). The syntax and semantics of complex nominals. New York: Academic Press.

Lewis, G. (2000). Turkish grammar, 2nd edn. New York: Oxford University Press. 
Lieber, R. (2004). Morphology and lexical semantics. Cambridge: Cambridge University Press.

Lieber, R. ve Scalise, S. (2006). The Lexical Integrity Hypothesis in a new theoretical universe. Lingue e Linguaggio (5), 7-32.

Partee, B. (1995). Lexical semantics and compositionality. L. Gleitman and M. Liberman (Yay.), Invitation to cognitive science, 2nd edn., Part I: Language, (ss. 311-360). Cambridge: MIT Press.

Plank, F. (1991). Rasmus Rask's dilemma. F. Plank (Yay.), Paradigms: The economy of inflection, (ss. 161196). Berlin: Mouton de Gruyter.

Pounder, A. (2000). Processes and paradigms in word-formation morphology. Berlin: Mouton de Gruyter.

Sadock, J. M. (2012). The modular architecture of grammar. Cambridge: Cambridge University Press.

Schaaik, G. van. (1996). Studies in Turkish grammar. Turcologica 28. Wiesbaden: Harrassowitz.

Schaaik, G. van (2002). The noun in Turkish. Its argument atructure and the compounding straitjacket. Wiesbaden: Harrassowitz Verlag.

Schroeder, C. (1999). The Turkish nominal phrase in spoken discourse. Wiesbaden: Harrassowitz.

Spencer, A. (2001). The paradigm-based model of morphosyntax. Transactions of the Philological Society (99), 279-313.

Spencer, A. (2011). What is in a compound? Journal of Linguistics (47), 481-507.

Stump, G. (1991). A paradigm-based theory of morphosemantic mismatches. Language (67), 675-725.

Stump, G. (2001). Inflectional morphology. Cambridge: Cambridge University Press.

Underhill, R. (1976). Turkish grammar. Cambridge: MIT.

Uygun, D. (2009). A split model for category specification: Lexical categories in Turkish (Doktora Tezi). Boğaziçi University.

Uzun, N. E. (1994). Türkçede bileşiğin biçimlenişi: Varsayımsal taban yaklaşımıyla yeni bir sınıflama. Dilbilim Araştırmaları Dergisi, 1994, 128-140.

Uzun, N. E. (2001). Anaçizgileriyle evrensel dilbilgisi ve Türkçe. İstanbul: Multilingual Yayınları.

Uzun, N. E. (2006). Biçimbilim: Temel kavramlar. İstanbul: Papatya Yayıncılık.

Wurzel, W. (1989) Inflectional morphology and Naturalness. Dordrecht: Kluwer.

Yükseker, H. (1987). Turkish nominal compounds. P. Avery ve H. Yükseker (Yay.), Toronto working papers in linguistics 7, (ss. 83-102). Toronto: Department of Linguistics, University of Toronto.

Yükseker, H. (1994). Possessive constructions in Turkish. L. Johanson (Yay.), Proceedings of the seventh international conference on Turkish linguistics, (ss. 458-477). Wiesbaden: Harrassowitz.

Yükseker, H. (1998). Turkish possessive compounds. G. Booij, A. Ralli ve S. Scalise (Yay.), Proceedings of the first Mediterranean conference on morphology, (ss. 153-164). Greece: University of Patras.

Zwicky, A. M. (1986). The general case: Basic form vs. default form. D. Feder, M. Niepokuj, V. Nikiforidou ve M. van Clay (Yay.), Proceedings of the annual meeting of Berkeley Linguistics Society 12, (ss. 305-314). Berkeley: Berkeley Linguistics Society.

Zwicky, A. M. (1987a). Transformational grammarians and their ilk. MITWPL (9), 265-279.

Zwicky, A. M. (1987b). Suppressing the Z's. Journal of Linguistics (23), 133-148. 